$1-1-1975$

\title{
Poultry, seafood, and lunch meat consumption in West Virginia
}

John P. Kuehn

James W. Bias

Follow this and additional works at: https://researchrepository.wvu.edu/ wv_agricultural_and_forestry_experiment_station_bulletins

\section{Digital Commons Citation}

Kuehn, John P. and Bias, James W., "Poultry, seafood, and lunch meat consumption in West Virginia" (1975). West Virginia Agricultural and Forestry Experiment Station Bulletins. 638.

https://researchrepository.wvu.edu/wv_agricultural_and_forestry_experiment_station_bulletins/545 @ WVU. It has been accepted for inclusion in West Virginia Agricultural and Forestry Experiment Station Bulletins by an authorized administrator of The Research Repository @WVU. For more information, please contact ian.harmon@mail.wvu.edu. 
pultry,

leafood, and Lunch Meat

lonsumption

West Virginia

1lletin 638

erch 1975

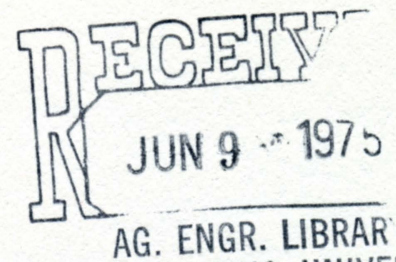

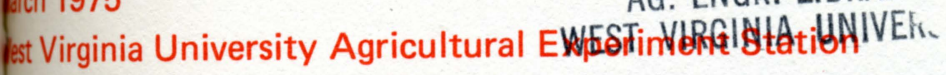

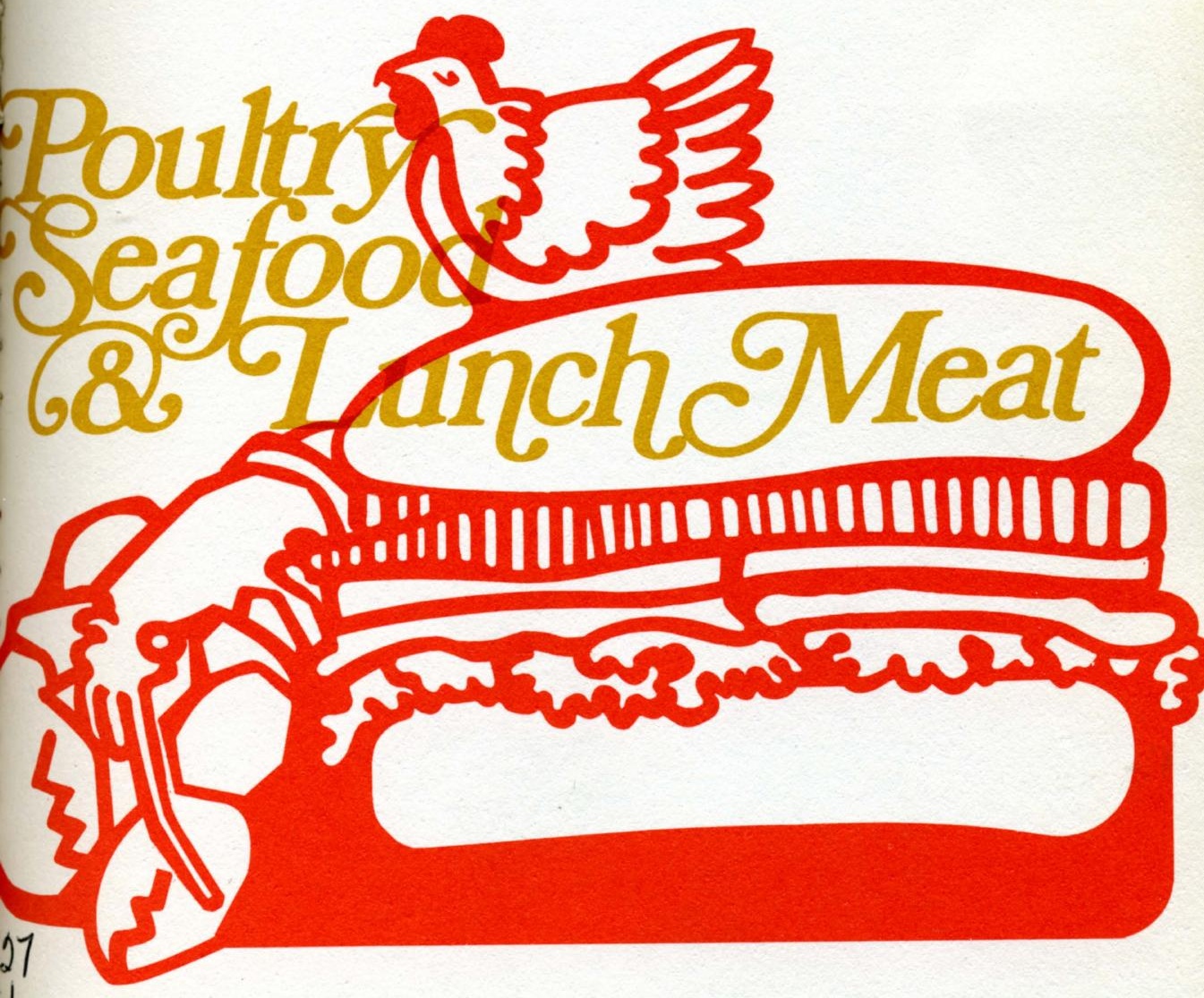


[Blank Page in Original Bulletin] 


\section{SUMMARY AND CONCLUSIONS}

Generally, the place of residence had more of an effect on poultry consumption than on seafood or lunch meat. Rural residents consumed more poultry than middle or urban respondents, but they consumed slightly less seafood. Urban residents consumed the smallest amount of lunch meat per capita, followed by rural and then middle county residents with the highest consumption per person.

Single people in the survey consumed more poultry, seafood, and lunch meat per capita than families of similar socioeconomic status, as substantiated by the regression analysis.

Age of the principal income earner was a significant factor resulting in higher per capita poultry consumption by older households. Age of the principal income earner did not appear to be significant in the cases of seafood and lunch meat consumption.

Grade school graduates consumed less poultry per capita, households with less than 15 years of education consumed less seafood per person, and the 0-7 years of education category consumed more lunch meat per capita than households in other educational categories.

Self employed principal income earners consumed more poultry, and professional, unemployed, and white collar households in similar socioeconomic groups consumed less lunch meat per capita than other occupational categories.

As household size increased, poultry and seafood consumption per capita decreased. There did not appear to be a significant relationship between household size and lunch meat consumption.

Ten per cent price increases were found to be associated with decreases in per capita consumption of 2.3 per cent in the case of poultry, 0.9 per cent in the case of seafood, and 1.4 per cent in lunch meat consumption. A 10 per cent increase in the price of beef was associated with a 1.4 per cent increase in the quantity of lunch meat consumed per capita. This evaluation implied that as beef prices rise, people purchase more lunch meat and less beef.

Principal income earners in the $\$ 5,000$ to $\$ 9,999$ category purchased the largest per capita amounts of both poultry and lunch meat and paid the highest prices of all other income categories. In the case of seafood, the largest amount purchased per person and the highest price per pound was accounted for by households whose income exceeded $\$ 25,000$. In the regression analysis, however, income did not appear to be a statistically significant factor in the consumption of any of the products. 


\title{
THE AUTHORS
}

John P. Kuehn is Associate Agricultural Economist; at the time of this study, James W. Bias was a Graduate Research Assistant.

\author{
West Virginia University \\ Agricultural Experiment Station \\ College of Agriculture and Forestry \\ Homer C. Evans, Acting Director \\ Morgantown
}




\title{
Poultry, Seafood, and Lunch Meat Consumption in West Virginia
}

\author{
John P. Kuehn and James W. Bias
}

The onset of the decade of the 1970s has proven to be a tumultuous one in terms of American agriculture. International shortages of grain and other agricultural products, due to increasing populations and inclement weather along with an almost worldwide inflation and energy shortage, have caused significant changes in both the levels and distribution of agricultural prices in the United States.

Between 1960 and March 1973 the prices of all consumer goods increased 46 per cent, as measured by the Consumer Price Index $(1967=100) .{ }^{1}$ The prices of meat, poultry, and fish increased 71 per cent during that same period. However, 39 per cent of that increase took place during 1972 and the first three months of 1973 , while the prices of all items increased only 11 per cent. $^{2}$

In spite of these price increases, beef consumption per capita increased from 85.1 pounds in 1960 to 114.8 pounds in 1972 . Pork consumption remained relatively stable during that period (64.9 to 67.7 pounds per capita). Fish consumption also remained relatively stable, only increasing from 10.3 pounds per capita in 1960 to 11.4 pounds per person in 1972. Chicken consumption, however, increased from 28.1 to 42.9 pounds. This increase of 53 per cent was greater than the 35 per cent increase in per capita beef consumption, ${ }^{3}$ although it can be noted that the absolute increase in chicken consumption was only about 15 pounds compared with nearly 30 pounds for beef.

Obviously, our agricultural sector is undergoing significant changes which could have far reaching effects on the lifestyles of everyone, and we must attempt to understand these changes.

\section{OBJECTIVES}

The overall objective of this study is to examine the nature of West Virginia's meat consumption characteristics and the socioeconomic factors

${ }^{1}$ Statistical Abstract of the United States, 1973, U. S. Dept. of Commerce, Social and Economic Statistics Administration, Bureau of the Census, Washington: U.S. Govt. Printing Office, July 1973, p. 354.

\footnotetext{
${ }^{2}$ Ibid.

3lbid., p. 87
} 
which affect them. Information gained from this study provides a picture of the State's consumption behavior to the meat industry and to the consumer. Because the industry and our economic and social character are undergoing change, an objective of this research program is to repeat this survey during the summer of 1975 to determine the nature and magnitude of any changes in meat consumption habits taking place since the summer of 1973.

The specific objectives are:

1. To estimate the weekly per capita consumption of poultry, seafood, and lunch meat and the average price paid per pound for each by households in West Virginia.

2. To compare these estimates to associated socioeconomic characteristics of households in the State as a whole and in a stratification of the counties of the State based on three different ranges of population density.

3. To determine the nature and magnitude of the statistical relationships between the weekly per capita consumption of poultry, seafood, and lunch meat and the factors thought to influence consumption patterns.

4. To repeat the analysis in the summer of 1975 using the same sampling techniques and to compare the results of the above objectives for both time periods.

This report is a presentation of the results and analysis of objectives one, two, and three for the survey conducted in the summer of 1973. Objective four is being conducted at the time of this writing and a subsequent bulletin will follow.

The entire study is concerned with an analysis of the consumption of beef and pork, as well as chicken, seafood, and lunch meat. This bulletin is concerned only with the latter three meats. A previous report (Bulletin 637) discussed the results for beef and pork consumption in West Virginia.

\section{PROCEDURE}

The State's 55 counties were divided into three classes on the basis of the 1970 population per square mile. Counties having a population of 20 or fewer people per square mile were classified as "rural" (Figure 1). These nine counties contained approximately 6.5 per cent of the State's population. The counties having more than 20 people per square mile but fewer than 100 were classified as "middle" (Figure 2). The 31 "middle" counties contain 53 per cent of the State's population. The counties having a population of 100 or more people per square mile were classified as "urban" (Figure 3). About 40.5 per cent of the State's population is located in them.

From each county classification group, a random sample of counties was selected to be representative of the respective category. A total of 18 counties was randomly selected and divided as follows: three "rural," ten "middle," and 


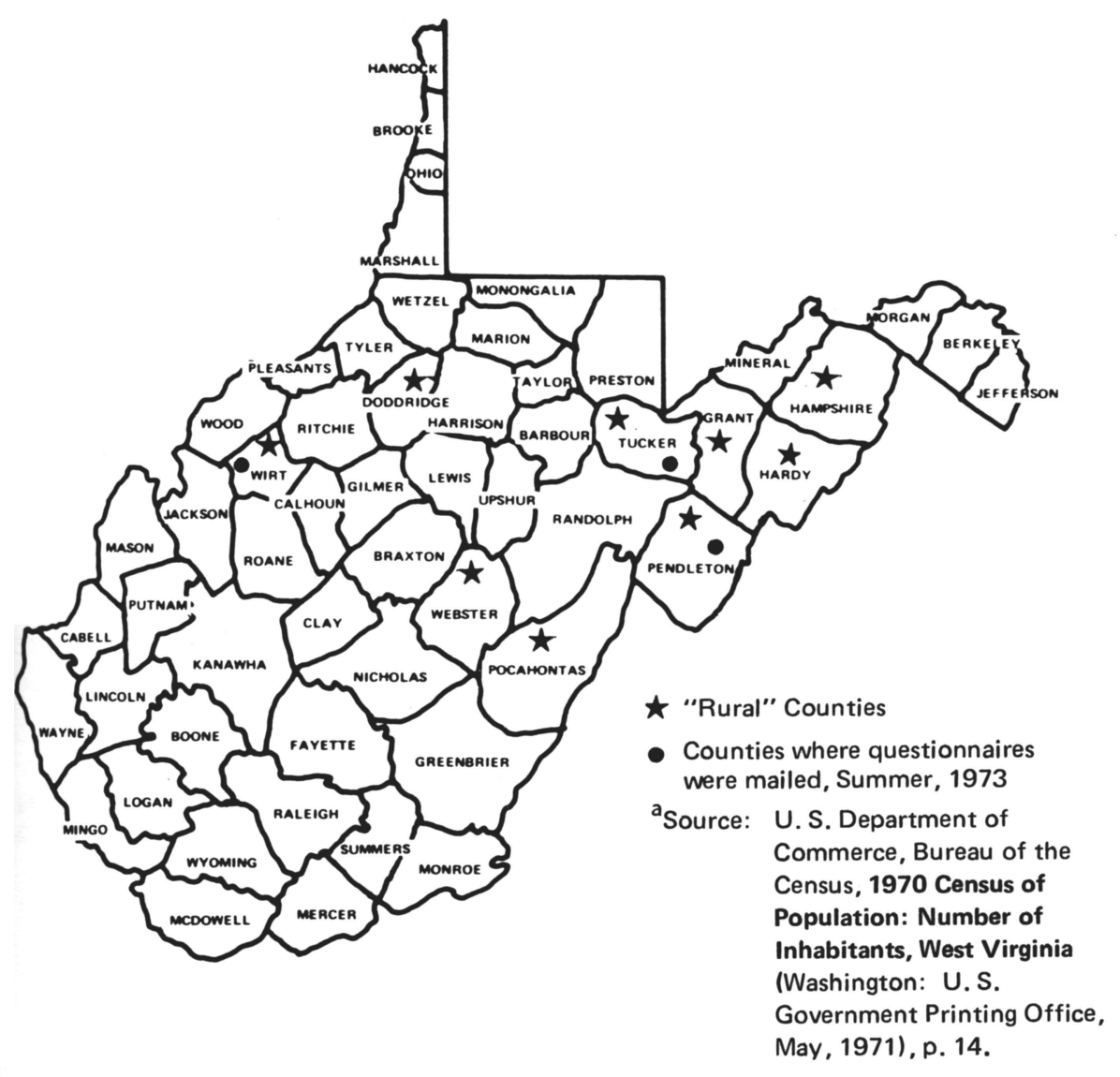

Figure 1. "Rural" Counties: West Virginia Counties with 20 or Fewer People Per Square Mile, $1970^{\mathrm{a}}$.

five "urban." The number of randomly selected counties in each category was proportional to the share of the State's population in that category.

After the counties in each classification group were randomly selected, the names of potential respondents were chosen randomly from the respective area telephone directories. The sample consisted of approximately 2,000 names. A minimum return of 20 per cent (from this sample size) was the goal of this survey. At least 400 consumer responses were required to assure a 95 per cent level of confidence that the sample was representative of the population. ${ }^{4}$

Approximately 2,000 questionnaires were mailed to the potential respondents. ( $A$ copy of the mail questionnaire is presented in the Appendix.) These

${ }^{4}$ New York State Division of Housing, A Method for Employing Sampling Techniques in Housing Surveys, New York: New York State Division of Housing, September, 1948, p. 136. 


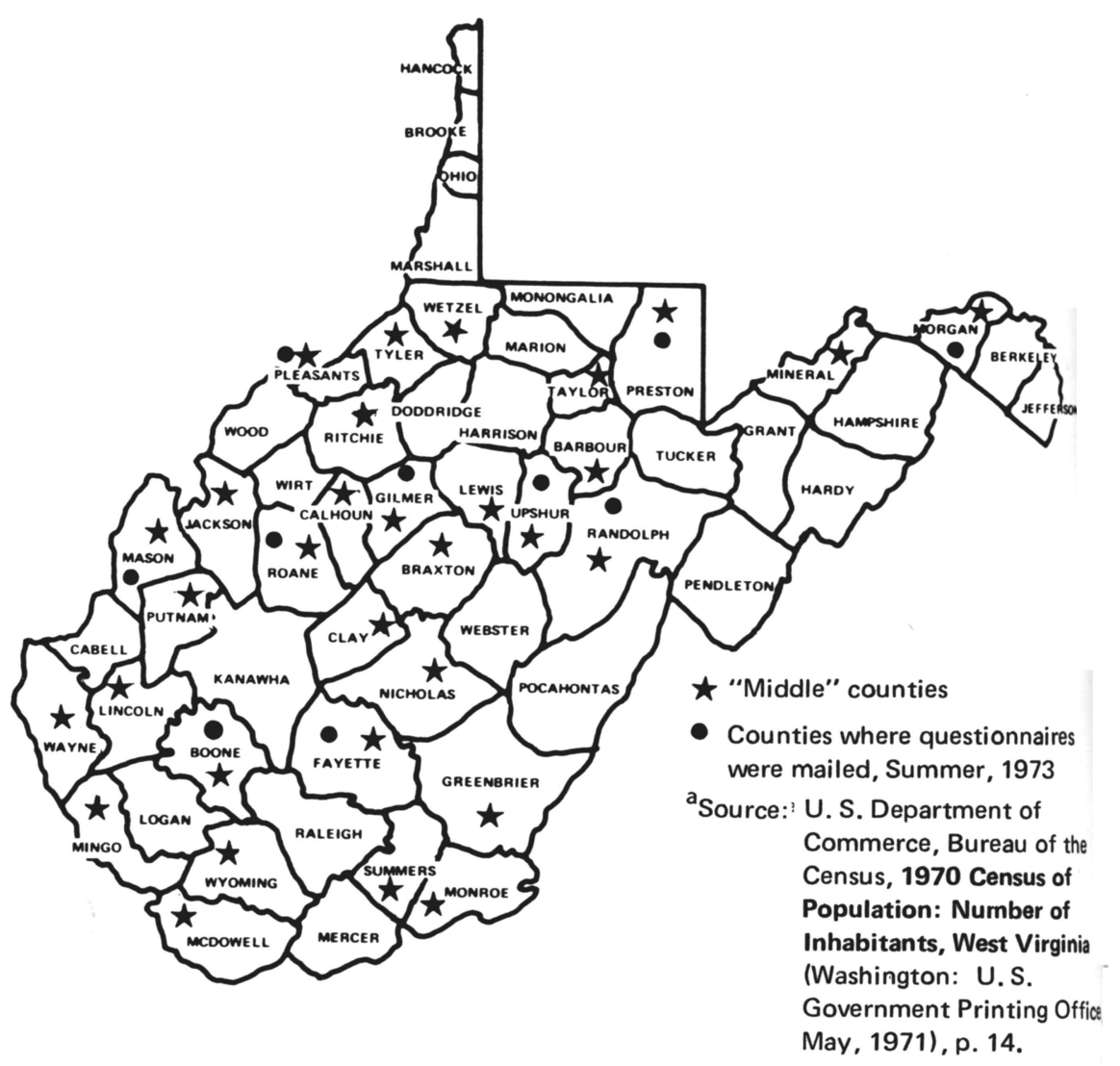

Figure 2. "Middle" Counties: West Virginia Counties with More Than 20 But Fewer Than 100 People Per Square Mile, 1970 .

questionnaires were distributed to the different classes of counties according to the proportion of population that each contained. Accordingly, about 130 questionnaires were sent to "rural" counties, about 1,060 to "middle" counties, and about 810 to "urban" counties.

The first mailing was made on July 30,1973 . Follow-up letters were sent to those counties from which the response was inadequate. Of the more than 2,000 questionnaires mailed, 502 , or about 25 per cent, were returned. However, only 450 usable questionnaires were obtained - 60 from "rural" counties, 207 from "middle" counties, and 183 from "urban" counties. Some respondents failed, or refused, to answer all questions on the mail questionnaires. As a consequence, some tables do not include data from all questionnaires.

The mail questionnaires were addressed to the family member most responsible for meat purchasing. Each was asked to report on the consumption of 


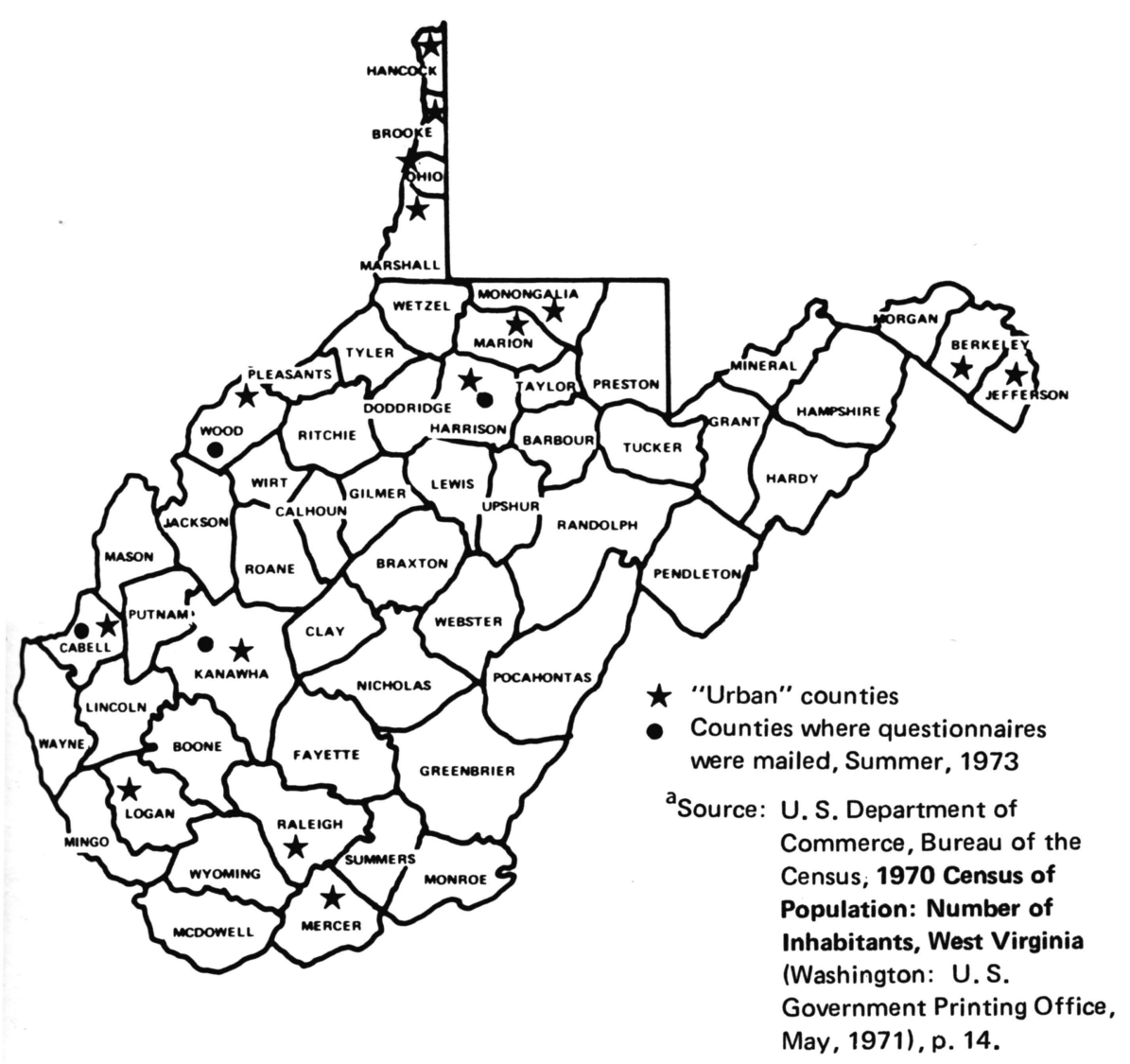

Figure 3. "Urban" Counties: West Virginia Counties with 100 or More People Per Square Mile, $1970^{\mathrm{a}}$.

various meats by his or her household during a seven-day period, either preceding or following the day the questionnaire was received.

\section{SURVEY RESULTS}

\section{Family Member Most Responsible for Meat Purchasing}

About 72 per cent of the respondents reported that the wife was most responsible for meat purchasing (Appendix Table 1). The husband was primarily responsible in 15 per cent of the households surveyed and in four per cent of the households the husband and wife shared this responsibility equally. Nine per cent of the respondents were single.

Poultry. In households where the wife was the family member most responsible for meat purchasing, more poultry was purchased per capita at higher prices 
(Table 1). (Single people, however, purchased more poultry per capita and paid more per pound than did married persons.)

In general, more poultry was purchased per capita at higher prices by rural households. Families in the middle counties purchased more poultry per capita than urban households, but they paid lower prices per pound.

(However, the presence or absence of price differentials between rural and urban areas was not analyzed. Also, the questionnaire (see Appendix) did not specifically determine the quantities of meat consumed from home freezers. This study was concerned with purchases during one specific week and did not in. clude meat consumed during that week which was purchased previously, or restaurant and other consumption of meat which was not purchased directly for home use.)

Seafood. Married households where the wife purchased the meat consumed more seafood and paid more per pound (Table 2). Single people purchased more seafood than married people. In general, they did not report paying as high a price per pound as the wife category.

Rural households purchased less seafood per capita than families in middle and rural areas. Middle county residents purchased more seafood per capita and paid higher prices than either rural or urban households.

Lunch Meat. As in the cases of poultry and seafood, families where the wife was most responsible for meat purchasing bought more lunch meat per capita and paid more per pound than households where the husband held that responsibility (Table 3). Also, as in the cases of poultry and seafood, single people purchased more lunch meat per capita than married people.

Households in the middle counties purchased more lunch meat than families in either rural or urban counties. A lower price per pound was reported in the urban areas.

\section{Principal Income Earner}

In 84 per cent of the households surveyed, the husband was the principal income earner (Appendix Table 1). The wife was the main income earner in seven per cent of the households. Nine per cent of the respondents were single.

Poultry. Families where the wife was the principal income earner purchased more poultry and paid more per pound than families where the husband earned the greater proportion of the household income (Table 4). Single people, however, purchased more poultry per capita than families.

Although all households in general purchased less poultry in urban areas than in rural counties, households in rural areas where the wife was the principal income earner purchased less poultry than her urban counterparts.

Seafood. Households where the wife was the principal income earner purchased more seafood per capita than families with the husband in this role. However, the latter category paid more per pound than families where the wives 
earned the majority of the income (Table 5). Single people purchased more seafood per capita than families.

Lunch Meat. The husbands again purchased less and paid less per pound than wives who were principal income earners (Table 6). Also, single people in the survey purchased more lunch meat per capita and paid more per pound than both of the other principal income earner categories.

\section{Age of the Principal Income Earner}

The majority of the principal income earners surveyed were in the 45 to 64 age group (Appendix Table 1). The proportion of households whose major income earner was in this category increased from 33 per cent in the rural counties, to 45 per cent in the middle counties, and to 49 per cent in the urban counties. However, the proportion of principal income earners who were in the over 65 category was significantly higher in the rural counties than in the middle or urban counties.

Poultry. There appeared to be a general trend toward increasing the consumption of poultry per capita with increasing age of the principal income earner (Table 7). Prices per pound also followed this trend. The exception was families whose principal income earner was under 25. They consumed more per capita than the 25-34 category but less than all other categories. However, this group (under 25) paid the second highest price per pound of all age groups. Households whose main income earner was over 65 purchased the greatest amount of poultry per capita and paid a significantly higher price per pound than all other categories.

Seafood. Although there appeared to be no definite trends for the State, families where the principal income earner was under 25 purchased more seafood per capita and paid a higher price per pound than did any other group (Table 8). The 25-34 age group consumed the least per capita and paid the lowest price per pound.

Lunch Meat. There appeared to be a trend toward lower consumption and prices paid by older households than those with younger principal income earners (Table 9). This trend was found in the rural and middle counties, but in the urban counties the 25-34 and 35-44 age categories accounted for the lowest per capita consumption.

\section{Education of the Principal Income Earner}

Of the 450 respondents in the study, six per cent did not graduate from grade school (Appendix Table 1). Sixteen per cent were grade school graduates and 31 per cent were high school graduates. Eight per cent of those surveyed were college graduates and 14 per cent fell into the category of more than 16 years of education, or postgraduate study.

There was a significantly larger proportion of principal income earners in 
the zero to seven years of education category (less than a grade school graduate) in the rural counties than in the middle or urban groups. Eighteen per cent of the rural sample did not graduate from grade school while only four and five per cent of principal income earners fell into this category in the middle and urban counties, respectively.

The proportion of principal income earners who graduated from college and those who studied additionally was higher in the more populated areas. These two categories accounted for five per cent of the sample in the rural counties, 18 per cent in the middle counties, and 33 per cent in the urban areas of West Virginia.

Poultry. Principal income earners with 16 years of education (college graduates) consumed the smallest amount of poultry per capita (Table 10). This category also paid a lower price per pound than respondents in any of the other educational categories. The greatest amount of poultry purchased per capita and the highest price paid was by principal income earners in the 9 to 11 years of education (not quite a high school graduate) category.

Seafood. There appeared to be a trend of increasing per capita seafood consumption as education increased (Table 11). The same trend was also reflected in prices paid per pound. One exception to the trend was the 16 years of education (college graduate) category. This group of principal income earners consumed less seafood per capita than the 9 to 11 year category. The trend of increasing seafood consumption with increasing education appeared to be more pronounced in the more populated areas of the sample.

Lunch Meat. People in the 0 to 7 years of education category consumed more lunch meat per capita than any of the other groups (Table 12) and they also paid the highest price per pound. The 16 years of education category (college graduate) consumed and paid the least.

\section{Occupation of the Principal Income Earner}

Professionals accounted for a large proportion of principal income earners surveyed in the State (Appendix Table 1), with 18 per cent of the respondents. Seventeen per cent of those surveyed were retired and 16 per cent were laborers. White collar workers were next (11 per cent). The smallest proportion of respondents was in the unemployed category (only 1.11 per cent).

There were substantially more professional people in urban areas $(28$ per cent) than in rural areas ( 5 per cent), and there were also more white collar workers ( 17 per cent) in urban areas than in rural areas ( 3 per cent). There were twice as many laborers in rural areas (20 per cent) than in urban areas (10 per cent). The proportion of unemployed respondents was the lowest in the middle counties ( 0.97 per cent). This was followed by the urban areas (1.09 per cent) and the rural counties (1.67 per cent). 
Poultry. Generally, families in the State where a housewife was also the principal income earner purchased the greatest amount of poultry per capita and paid a significantly higher price than any of the other occupational categories (Table 13). This was especially evident in middle and urban counties, but in rural areas, machine operators and retired households purchased more poultry at higher prices. Farmers and white collar workers, on a State basis, purchased the smallest amount of poultry and paid lower prices than the other occupational categories.

Seafood. Households where the principal income earner was self-employed purchased the smallest quantity of seafood per person and paid the second lowest price per pound (Table 14). Farmers also purchased a small quantity of seafood compared to other occupational categories and paid a lower price per pound than any other occupational group. The greatest quantity of seafood per person was purchased by families with unemployed household heads. They also paid the highest price per pound. However, it should be noted again that only five of the 450 respondents were unemployed.

Lunch Meat. Retired people, followed by farmers, purchased the smallest quantities of lunch meat per capita, and farmers reported paying the lowest price per pound (Table 15). Households where the principal income earner was a housewife or sales and clerical worker purchased more than any of the other occupational categories, and they paid a significantly higher price per pound.

\section{Household Size}

The most commonly occurring household size encountered in this survey was two people-32 per cent (Appendix Table 1). Twenty-two per cent were families of four, 20 per cent were families of three, and 10 per cent were five-person households. One nine-member family and one 10-member family also responded.

Poultry. There appeared to be a general trend in the State toward decreasing per capita consumption of poultry, associated with increasing family size (Table 16). One major exception was that of households with seven people, who consumed the third highest quantity of poultry per capita and paid the third highest price per pound.

Seafood. Families of two purchased the largest amount of seafood per person and paid the highest price per pound (Table 17). Households with four people purchased the smallest amount of seafood per capita.

There appeared to be no major price or consumption differences between rural, middle, and urban counties in this survey.

Lunch Meat. Single people purchased the largest quantity of lunch meat per capita and paid the highest price per pound (Table 18). Families of two and four purchased the smallest amounts per person and paid the lowest price per pound. 
There appeared to be no significant relationship between family size and either quantity purchased or price paid.

\section{Total Annual Household Income}

The most commonly occurring household income in the State sample was $\$ 5,000$ to $\$ 9,999$ (Appendix Table 1). Thirty-one per cent of the households fell into this category. Twenty-five per cent of those sampled earned $\$ 10,000$ to $\$ 14,999,18$ per cent earned $\$ 1,000$ to $\$ 4,999$, and 17 per cent fell in the $\$ 15,000$ to $\$ 24,999$ range. Only three per cent earned less than $\$ 1,000$ and only 6 per cent earned more than $\$ 25,000$. Incomes tended to be higher in the middle and urban counties than in the rural areas. Urban areas had fewer low income households and more higher income households than rural areas.

Poultry. Principal income earners in the $\$ 5,000-\$ 9,999$ category purchased the largest quantity of poultry per capita and paid the highest price per pound (Table 19). Respondents in the under $\$ 1,000$ category purchased the smallest quantity and paid the least per pound.

Seafood. In the case of seafood, there appeared to be an increase in per capita consumption and price paid per pound as incomes increased (Table 20). The greatest amount of seafood purchased per person was by families in the $\$ 25,000$ and over category. This group also paid the highest price per pound.

Lunch Meat. Households in the $\$ 5,000$ to $\$ 9,999$ category purchased the largest amount of lunch meat per capita and paid the highest price per pound of all income categories (Table 21). The smallest quantity of lunch meat purchased per capita and the lowest price paid per pound were reported by respondents in the over $\$ 25,000$ category.

\section{Statistical Analysis}

Multiple regression analysis was used to statistically determine the effects of the various socioeconomic variables on weekly per capita poultry, seafood, and lunch meat consumption in West Virginia. The most significant of these variables are shown in Tables 22, 23, and 24.

Although there are many other factors involved, there are a few general conclusions that can be derived from the more statistically significant results of the equations.

Poultry.

1. Rural residents tended to consume more poultry per capita than similar middle or urban households.

2. Single people with similar traits tended to consume more poultry per capita than families.

3. As the age of the principle income earner increased, household consumption of poultry per person tended to increase. 
4. Grade school graduates, in similar socioeconomic categories consumed less poultry than households whose principal income earners were in different educational categories.

5. Self employed people of similar socioeconomic status consumed slightly more poultry than the average of other occupational categories.

6. As household size increased, poultry consumption decreased.

7. As the price of poultry increased ten per cent, the quantity consumed per capita decreased by 2.3 per cent.

Seafood.

1. Single people consumed more seafood per capita than families.

2. Households whose principal income earner had less than 15 years of education consumed less seafood per capita than more educated households in similar socioeconomic categories.

3. As household size increased, per capita consumption of seafood decreased.

4. A 10 per cent increase in the price of seafood was associated with a 0.9 per cent decrease in per capita consumption.

Lunch Meat.

1. Single people in similar socioeconomic categories consumed more lunch meat per capita than families.

2. The $0-7$ years of education category (not a grade school graduate) consumed more lunch meat per capita than other educational categories.

3. Professional, unemployed, and white collar income earners consumed less lunch meat per capita than households in other occupational categories.

4. As the price of beef increased 10 per cent, per capita consumption of lunch meat increased 1.4 per cent.

5. As the price of lunch meat increased 10 per cent, per capita consumption of lunch meat decreased 1.4 per cent. 


\section{TABLE 1}

POULTRY: The Weekly Per Capita Consumption and the Average Price Paid Per Pound by Households Relative to the Family Member Most Responsible

for Meat Purchasing, Summer, 1973.

\begin{tabular}{|c|c|c|c|c|c|c|c|c|c|c|c|c|}
\hline \multirow{2}{*}{$\begin{array}{l}\text { Family Member } \\
\text { Most Responsible } \\
\text { for Meat } \\
\text { Purchasing } \\
\end{array}$} & \multicolumn{3}{|c|}{ STATE } & \multicolumn{3}{|c|}{ RURAL } & \multicolumn{3}{|c|}{ MIDDLE } & \multicolumn{3}{|c|}{ URBAN } \\
\hline & Responses & Lbs. & Price & Responses & Lbs. & Price & Responses & Lbs. & Price & Responses & Lbs. & Price \\
\hline Wife & 322 & 0.69 & $\$ 0.73$ & 45 & 0.86 & $\$ 0.88$ & 151 & 0.67 & $\$ 0.70$ & 126 & 0.63 & $\$ 0.70$ \\
\hline Husband & 69 & 0.66 & 0.67 & 10 & 0.72 & 0.69 & 31 & 0.68 & 0.65 & 28 & 0.61 & 0.67 \\
\hline Single & 39 & 0.95 & 1.14 & 4 & 1.38 & 1.75 & 18 & 1.13 & 1.01 & 17 & 0.67 & 1.14 \\
\hline $\begin{array}{l}\text { Both Wife and } \\
\text { Husband }\end{array}$ & 20 & 0.61 & 0.64 & 1 & 0.00 & 0.00 & 7 & 0.39 & 0.48 & 12 & 0.79 & 0.78 \\
\hline All Households & 450 & 0.70 & $\$ 0.75$ & 60 & 0.86 & $\$ 0.89$ & 207 & 0.71 & $\$ 0.71$ & 183 & 0.64 & $\$ 0.74$ \\
\hline
\end{tabular}




\section{TABLE 2}

SEAFOOD: The Weekly Per Capita Consumption and the Average Price Paid Per Pound by Households Relative to the Family Member Most Responsible for Meat Purchasing, Summer, 1973.

\begin{tabular}{|c|c|c|c|c|c|c|c|c|c|c|c|c|}
\hline \multirow{2}{*}{$\begin{array}{l}\text { Family Member } \\
\text { Most Responsible } \\
\text { for Meat } \\
\text { Purchasing } \\
\end{array}$} & \multicolumn{3}{|c|}{ STATE } & \multicolumn{3}{|c|}{ RURAL } & \multicolumn{3}{|c|}{ MIDDLE } & \multicolumn{3}{|c|}{ URBAN } \\
\hline & Responses & Lbs. & Price & Responses & Lbs. & Price & Responses & Lbs. & Price & Responses & Lbs. & Price \\
\hline Wife & 322 & 0.27 & $\$ 0.39$ & 45 & 0.27 & $\$ 0.38$ & 151 & 0.26 & $\$ 0.34$ & 126 & 0.28 & $\$ 0.32$ \\
\hline Husband & 69 & 0.26 & 0.31 & 10 & 0.19 & 0.24 & 31 & 0.35 & 0.41 & 28 & 0.20 & 0.22 \\
\hline Single & 39 & 0.29 & 0.34 & 4 & 0.25 & 0.25 & 18 & 0.33 & 0.33 & 17 & 0.25 & 0.37 \\
\hline $\begin{array}{l}\text { Both Wife and } \\
\text { Husband }\end{array}$ & 20 & 0.21 & 0.39 & 1 & 0.00 & 0.00 & 7 & 0.21 & 0.28 & 12 & 0.23 & 0.49 \\
\hline All Households & 450 & 0.27 & $\$ 0.34$ & 60 & 0.25 & $\$ 0.34$ & 207 & 0.28 & $\$ 0.35$ & 183 & 0.26 & $\$ 0.32$ \\
\hline
\end{tabular}


TABLE 3

LUNCH MEAT: The Weekly Per Capita Consumption and the Average Price Paid

Per Pound by Households Relative to the Family Member Most Responsible for Meat Purchasing, Summer, 1973.

\begin{tabular}{|c|c|c|c|c|c|c|c|c|c|c|c|c|}
\hline \multirow{2}{*}{$\begin{array}{l}\text { Family Member } \\
\text { Most Responsible } \\
\text { for Meat } \\
\text { Purchasing } \\
\end{array}$} & \multicolumn{3}{|c|}{ STATE } & \multicolumn{3}{|c|}{ RURAL } & \multicolumn{3}{|c|}{ MIDDLE } & \multicolumn{3}{|c|}{ URBAN } \\
\hline & Responses & Lbs. & Price & Responses & Lbs. & Price & Responses & Lbs. & Price & Responses & Lbs. & Price \\
\hline Wife & 322 & 0.39 & $\$ 0.52$ & 45 & 0.34 & $\$ 0.49$ & 151 & 0.43 & $\$ 0.55$ & 126 & 0.36 & $\$ 0.50$ \\
\hline Husband & 69 & 0.32 & 0.39 & 10 & 0.37 & 0.40 & 31 & 0.36 & 0.45 & 28 & 0.27 & 0.33 \\
\hline Single & 39 & 0.67 & 0.85 & 4 & 1.00 & 1.50 & 18 & 0.56 & 0.67 & 17 & 0.71 & 0.88 \\
\hline $\begin{array}{l}\text { Both Wife and } \\
\text { Husband }\end{array}$ & 20 & 0.30 & 0.36 & 1 & 0.00 & 0.00 & 7 & 0.38 & 0.43 & 12 & 0.27 & 0.35 \\
\hline All Households & 450 & 0.40 & $\$ 0.52$ & 60 & 0.38 & $\$ 0.54$ & 207 & 0.43 & $\$ 0.54$ & 183 & 0.37 & $\$ 0.50$ \\
\hline
\end{tabular}


TABLE 4

POULTRY: The Weekly Per Capita Consumption and the Average Price Paid

Per Pound by Households Relative to the Principal Income Earner, Summer, 1973.

\begin{tabular}{|c|c|c|c|c|c|c|c|c|c|c|c|c|}
\hline \multirow{2}{*}{$\begin{array}{l}\text { Principal } \\
\text { Income } \\
\text { Earner }\end{array}$} & \multicolumn{3}{|c|}{ STATE } & \multicolumn{3}{|c|}{ RURAL } & \multicolumn{3}{|c|}{ MIDDLE } & \multicolumn{3}{|c|}{ URBAN } \\
\hline & Responses & Lbs. & Price & Responses & Lbs. & Price & Responses & Lbs. & Price & Responses & Lbs. & Price \\
\hline Husband & 378 & 0.67 & 0.67 & 51 & 0.85 & 0.85 & 176 & 0.66 & 0.66 & 151 & 0.61 & 0.63 \\
\hline Single & 39 & 0.95 & 1.14 & 4 & 1.38 & 1.75 & 18 & 1.13 & 1.01 & 17 & 0.67 & 1.14 \\
\hline
\end{tabular}

\section{TABLE 5}

SEAFOOD: The Weekly Per Capita Consumption and the Average Price Paid Per Pound by Households Relative to the Principal Income Earner, Summer, 1973.

\begin{tabular}{|c|c|c|c|c|c|c|c|c|c|c|c|c|}
\hline \multirow{2}{*}{$\begin{array}{l}\text { Principal } \\
\text { Income } \\
\text { Earner }\end{array}$} & \multicolumn{3}{|c|}{ STATE } & \multicolumn{3}{|c|}{ RURAL } & \multicolumn{3}{|c|}{ MIDDLE } & \multicolumn{3}{|c|}{ URBAN } \\
\hline & Responses & Lbs. & Price & Responses & Lbs. & Price & Responses & Lbs. & Price & Responses & Lbs. & Price \\
\hline Wife & 33 & 0.28 & $\$ 0.30$ & 5 & 0.42 & $\$ 0.70$ & 13 & 0.18 & $\$ 0.18$ & 15 & 0.33 & $\$ 0.28$ \\
\hline Husband & 378 & 0.26 & 0.34 & 51 & 0.24 & 0.32 & 176 & 0.28 & 0.37 & 151 & 0.25 & 0.32 \\
\hline Single & 39 & 0.29 & 0.34 & 4 & 0.25 & 0.25 & 18 & 0.33 & 0.33 & 17 & 0.25 & 0.37 \\
\hline All Households & 450 & 0.27 & $\$ 0.34$ & 60 & 0.25 & $\$ 0.34$ & 207 & 0.28 & $\$ 0.35$ & 183 & 0.26 & $\$ 0.32$ \\
\hline
\end{tabular}


TABLE 6

LUNCH MEAT: The Weekly Per Capita Consumption and the Average Price Paid Per Pound by Households Relative to the Principal Income Earner, Summer, 1973.

\begin{tabular}{|c|c|c|c|c|c|c|c|c|c|c|c|c|}
\hline \multirow{2}{*}{$\begin{array}{l}\text { Principal } \\
\text { Income } \\
\text { Earner }\end{array}$} & \multicolumn{3}{|c|}{ STATE } & \multicolumn{3}{|c|}{ RURAL } & \multicolumn{3}{|c|}{ MIDDLE } & \multicolumn{3}{|c|}{ URBAN } \\
\hline & Responses & Lbs. & Price & Responses & Lbs. & Price & Responses & Lbs. & Price & Responses & Lbs. & Price \\
\hline Wife & 33 & 0.51 & $\$ 0.69$ & 5 & 0.67 & $\$ 0.83$ & 13 & 0.39 & $\$ 0.51$ & 15 & 0.56 & $\$ 0.80$ \\
\hline Husband & 378 & 0.36 & 0.48 & 51 & 0.31 & 0.43 & 176 & 0.42 & 0.53 & 151 & 0.32 & 0.43 \\
\hline Single & 39 & 0.67 & 0.85 & 4 & 1.00 & 1.50 & 18 & 0.56 & 0.67 & 17 & 0.71 & 0.88 \\
\hline All Households & 450 & 0.40 & $\$ 0.52$ & 60 & 0.38 & $\$ 0.54$ & 207 & 0.43 & $\$ 0.54$ & 183 & 0.37 & $\$ 0.50$ \\
\hline
\end{tabular}




\section{TABLE 7}

POULTRY: The Weekly Per Capita Consumption and the Average Price Paid

Per Pound by Households Relative to the Age of the Principal Income Earner, Summer, 1973.

\begin{tabular}{|c|c|c|c|c|c|c|c|c|c|c|c|c|}
\hline \multirow{2}{*}{$\begin{array}{l}\text { Age of the } \\
\text { Principal } \\
\text { Income } \\
\text { Earner }\end{array}$} & \multicolumn{3}{|c|}{ STATE } & \multicolumn{3}{|c|}{ RURAL } & \multicolumn{3}{|c|}{ MIDDLE } & \multicolumn{3}{|c|}{ URBAN } \\
\hline & Responses & Lbs. & Price & Responses & Lbs. & Price & Responses & Lbs. & Price & Responses & Lbs. & Price \\
\hline Under 25 & 19 & 0.58 & $\$ 0.88$ & 3 & 0.72 & $\$ 1.17$ & 8 & 0.73 & $\$ 0.86$ & 8 & 0.36 & $\$ 0.78$ \\
\hline $25-34$ & 89 & 0.53 & 0.59 & 12 & 0.91 & 0.99 & 41 & 0.53 & 0.59 & 36 & 0.40 & 0.45 \\
\hline $35-44$ & 72 & 0.60 & 0.65 & 10 & 0.55 & 0.66 & 36 & 0.60 & 0.59 & 26 & 0.62 & 0.73 \\
\hline $45-54$ & 101 & 0.69 & 0.68 & 10 & 1.00 & 0.78 & 47 & 0.58 & 0.65 & 44 & 0.73 & 0.70 \\
\hline $55-64$ & 101 & 0.81 & 0.78 & 10 & 0.76 & 0.81 & 46 & 0.93 & 0.77 & 45 & 0.71 & 0.78 \\
\hline 65 and Over & 68 & 0.93 & 1.10 & 15 & 1.03 & 1.04 & 29 & 0.94 & 1.03 & 24 & 0.85 & 1.21 \\
\hline All Households & 450 & 0.70 & $\$ 0.75$ & 60 & 0.86 & $\$ 0.89$ & 207 & 0.71 & $\$ 0.71$ & 183 & 0.64 & $\$ 0.74$ \\
\hline
\end{tabular}




\section{TABLE 8}

SEAFOOD: The Weekly Per Capita Consumption and the Average Price Paid Per Pound by Households Relative to the Age of the Principal Income Earner, Summer, 1973.

\begin{tabular}{|c|c|c|c|c|c|c|c|c|c|c|c|c|}
\hline \multirow{2}{*}{$\begin{array}{l}\text { Age of the } \\
\text { Principal } \\
\text { Income } \\
\text { Earner }\end{array}$} & \multicolumn{3}{|c|}{ STATE } & \multicolumn{3}{|c|}{ RURAL } & \multicolumn{3}{|c|}{ MIDDLE } & \multicolumn{3}{|c|}{ URBAN } \\
\hline & Responses & Lbs. & Price & Responses & Lbs. & Price & Responses & Lbs. & Price & Responses & Lbs. & Price \\
\hline Under 25 & 19 & 0.39 & $\$ 0.57$ & 3 & 0.31 & $\$ 0.58$ & 8 & 0.60 & $\$ 0.76$ & 8 & 0.21 & $\$ 0.38$ \\
\hline $25-34$ & 89 & 0.21 & 0.30 & 12 & 0.14 & 0.21 & 41 & 0.25 & 0.38 & 36 & 0.20 & 0.23 \\
\hline $35-44$ & 72 & 0.26 & 0.30 & 10 & 0.20 & 0.30 & 36 & 0.28 & 0.28 & 26 & 0.25 & 0.31 \\
\hline $45-54$ & 101 & 0.33 & 0.42 & 10 & 0.29 & 0.43 & 47 & 0.32 & 0.41 & 44 & 0.35 & 0.43 \\
\hline $55-64$ & 101 & 0.24 & 0.31 & 10 & 0.11 & 0.17 & 46 & 0.25 & 0.30 & 45 & 0.27 & 0.35 \\
\hline 65 and Over & 68 & 0.26 & 0.30 & 15 & 0.43 & 0.50 & 29 & 0.21 & 0.28 & 24 & 0.20 & 0.20 \\
\hline All Households & 450 & 0.27 & $\$ 0.34$ & 60 & 0.25 & $\$ 0.34$ & 207 & 0.28 & $\$ 0.35$ & 183 & 0.26 & $\$ 0.32$ \\
\hline
\end{tabular}


TABLE 9

LUNCH MEAT: The Weekly Per Capita Consumption and the Average Price Paid

Per Pound by Households Relative to the Age of the Principal Income Earner, Summer, 1973.

\begin{tabular}{|c|c|c|c|c|c|c|c|c|c|c|c|c|}
\hline \multirow{2}{*}{$\begin{array}{l}\text { Age of the } \\
\text { Principal } \\
\text { Income } \\
\text { Earner } \\
\end{array}$} & \multicolumn{3}{|c|}{ STATE } & \multicolumn{3}{|c|}{ RURAL } & \multicolumn{3}{|c|}{ MIDDLE } & \multicolumn{3}{|c|}{ URBAN } \\
\hline & Responses & Lbs. & Price & Responses & Lbs. & Price & Responses & Lbs. & Price & Responses & Lbs. & Price \\
\hline Under 25 & 19 & 0.63 & $\$ 0.86$ & 3 & 0.50 & $\$ 0.78$ & 8 & 0.67 & $\$ 0.73$ & 8 & 0.64 & $\$ 1.02$ \\
\hline $25-34$ & 89 & 0.40 & 0.51 & 12 & 0.48 & 0.86 & 41 & 0.42 & 0.48 & 36 & 0.34 & 0.44 \\
\hline $35-44$ & 72 & 0.43 & 0.57 & 10 & 0.55 & 0.67 & 36 & 0.47 & 0.62 & 26 & 0.34 & 0.47 \\
\hline $45-54$ & 101 & 0.42 & 0.58 & 10 & 0.30 & 0.39 & 47 & 0.51 & 0.67 & 44 & 0.35 & 0.52 \\
\hline $55-64$ & 101 & 0.37 & 0.45 & 10 & 0.38 & 0.51 & 46 & 0.38 & 0.49 & 45 & 0.36 & 0.40 \\
\hline 65 and Over & 68 & 0.32 & 0.42 & 15 & 0.22 & 0.25 & 29 & 0.27 & 0.35 & 24 & 0.44 & 0.62 \\
\hline All Households & 450 & 0.40 & 0.52 & 60 & 0.38 & $\$ 0.54$ & 207 & 0.43 & $\$ 0.54$ & 183 & 0.37 & $\$ 0.50$ \\
\hline
\end{tabular}


TABLE 10

POULTRY: The Weekly Per Capita Consumption and the Average Price Paid

Per Pound by Households Relative to the Education of the Principal Income Earner, Summer, 1973.

\begin{tabular}{|c|c|c|c|c|c|c|c|c|c|c|c|c|}
\hline \multirow{2}{*}{$\begin{array}{l}\text { Education of the } \\
\text { Principal } \\
\text { Income } \\
\text { Earner }\end{array}$} & \multicolumn{3}{|c|}{ STATE } & \multicolumn{3}{|c|}{ RURAL } & \multicolumn{2}{|c|}{ MIDDLE } & & \multicolumn{2}{|c|}{ URBAN } & \\
\hline & Responses & Lbs. & Price & Responses & Lbs. & Price & Responses & Lbs. & Price & Responses & Lbs. & Price \\
\hline 0 to 7 Years & 28 & 0.77 & $\$ 0.85$ & 11 & 0.74 & $\$ 0.84$ & 8 & 0.91 & $\$ 0.91$ & 9 & 0.68 & $\$ 0.81$ \\
\hline $\begin{array}{l}8 \text { Years (grade } \\
\text { school graduate) }\end{array}$ & 71 & 0.66 & 0.63 & 16 & 0.97 & 0.92 & 41 & 0.56 & 0.51 & 14 & 0.59 & 0.66 \\
\hline 9 to 11 Years & 51 & 0.89 & 0.87 & 5 & 1.23 & 0.93 & 27 & 0.86 & 0.84 & 19 & 0.85 & 0.90 \\
\hline $\begin{array}{l}12 \text { Years (high } \\
\text { school graduate) }\end{array}$ & 138 & 0.69 & 0.79 & 19 & 0.71 & 0.73 & 70 & 0.68 & 0.67 & 49 & 0.69 & 1.00 \\
\hline 13 to 15 Years & 62 & 0.68 & 0.77 & 6 & 1.05 & 1.33 & 24 & 0.72 & 0.89 & 32 & 0.58 & 0.58 \\
\hline $\begin{array}{l}16 \text { Years (college } \\
\text { graduate) }\end{array}$ & 36 & 0.42 & 0.47 & 2 & 0.88 & 1.04 & 13 & 0.33 & 0.44 & 21 & 0.43 & 0.43 \\
\hline $\begin{array}{l}\text { More Than } 16 \\
\text { Years }\end{array}$ & 64 & 0.78 & 0.78 & 1 & 0.38 & 0.88 & 24 & 1.00 & 0.97 & 39 & 0.66 & 0.67 \\
\hline All Households & 450 & 0.70 & $\$ 0.75$ & 60 & 0.86 & $\$ 0.89$ & 207 & 0.71 & $\$ 0.71$ & 183 & 0.64 & $\$ 0.74$ \\
\hline
\end{tabular}


TABLE 11

SEAFOOD: The Weekly Per Capita Consumption and the Average Price Paid Per

Pound by Households Relative to the Education of the Principal Income Earner, Summer, 1973.

\begin{tabular}{|c|c|c|c|c|c|c|c|c|c|c|c|c|}
\hline \multirow{2}{*}{$\begin{array}{l}\text { Education of } \\
\text { the Principal } \\
\text { Income } \\
\text { Earner }\end{array}$} & \multicolumn{3}{|c|}{ STATE } & \multicolumn{3}{|c|}{ RURAL } & \multicolumn{3}{|c|}{ MIDDLE } & \multicolumn{3}{|c|}{ URBAN } \\
\hline & Responses & Lbs. & Price & Responses & Lbs. & Price & Responses & Lbs. & Price & Responses & Lbs. & Price \\
\hline $\begin{array}{l}0 \text { to } 7 \text { Years } \\
8 \text { Years (grade }\end{array}$ & 28 & 0.10 & $\$ 0.15$ & 11 & 0.13 & $\$ 0.24$ & 8 & 0.11 & $\$ 0.11$ & 9 & 0.04 & $\$ 0.07$ \\
\hline school graduate) & 71 & 0.22 & 0.25 & 16 & 0.38 & 0.39 & 41 & 0.18 & 0.23 & 14 & 0.13 & 0.16 \\
\hline $\begin{array}{l}9 \text { to } 11 \text { Years } \\
12 \text { Years (high }\end{array}$ & 51 & 0.24 & 0.31 & 5 & 0.34 & 0.34 & 27 & 0.24 & 0.28 & 19 & 0.20 & 0.32 \\
\hline school graduate) & 138 & 0.27 & 0.33 & 19 & 0.19 & 0.33 & 70 & $\begin{array}{l}0.28 \\
0.35\end{array}$ & 0.35 & 49 & $\begin{array}{l}0.29 \\
0.34\end{array}$ & 0.32 \\
\hline $\begin{array}{l}13 \text { to } 15 \text { Years } \\
16 \text { Years (college } \\
\text { graduate) } \\
\text { More Than } 16\end{array}$ & 36 & 0.25 & 0.32 & 2 & 0.46 & 0.71 & 13 & 0.19 & 0.25 & 21 & 0.26 & 0.34 \\
\hline Years & 64 & 0.37 & 0.47 & 1 & 0.38 & 1.13 & 24 & 0.50 & 0.67 & 39 & 0.29 & 0.33 \\
\hline All Households & 450 & 0.27 & $\$ 0.34$ & 60 & 0.25 & $\$ 0.34$ & 207 & 0.28 & $\$ 0.35$ & 183 & 0.26 & $\$ 0.32$ \\
\hline
\end{tabular}


TABLE 12

LUNCH MEAT: The Weekly Per Capita Consumption and the Average Price Paid

Per Pound by Households Relative to the Education of the Principal Income Earner, Summer, 1973.

\begin{tabular}{|c|c|c|c|c|c|c|c|c|c|c|c|c|}
\hline \multirow{2}{*}{$\begin{array}{l}\text { Education of } \\
\text { the Principal } \\
\text { Income } \\
\text { Earner }\end{array}$} & \multicolumn{3}{|c|}{ STATE } & \multicolumn{3}{|c|}{ RURAL } & \multicolumn{3}{|c|}{ MIDDLE } & \multicolumn{3}{|c|}{ URBAN } \\
\hline & Responses & Lbs. & Price & Responses & Lbs. & Price & Responses & Lbs. & Price & Responses & Lbs. & Price \\
\hline 0 to 7 Years & 28 & 0.50 & $\$ 0.59$ & 11 & 0.31 & $\$ 0.38$ & 8 & 0.66 & $\$ 0.67$ & 9 & 0.59 & $\$ 0.77$ \\
\hline $\begin{array}{l}8 \text { Years (grade } \\
\text { school graduate) }\end{array}$ & 71 & 0.39 & 0.46 & 16 & 0.38 & 0.39 & 41 & 0.44 & 0.54 & 14 & 0.23 & 0.30 \\
\hline 9 to 11 Years & 51 & 0.39 & 0.55 & 5 & 0.29 & 0.49 & 27 & 0.37 & 0.55 & 19 & 0.43 & 0.57 \\
\hline $\begin{array}{l}12 \text { Years (high } \\
\text { school graduate) }\end{array}$ & 138 & 0.48 & 0.62 & 19 & 0.39 & 0.61 & 70 & 0.47 & 0.56 & 49 & 0.51 & 0.71 \\
\hline 13 to 15 Years & 62 & 0.42 & 0.59 & 6 & 0.67 & 1.12 & 24 & 0.39 & 0.58 & 32 & 0.39 & 0.49 \\
\hline $\begin{array}{l}16 \text { Years (college } \\
\text { graduate) }\end{array}$ & 36 & 0.24 & 0.33 & 2 & 0.21 & 0.21 & 13 & 0.34 & 0.48 & 21 & 0.19 & 0.26 \\
\hline $\begin{array}{l}\text { More Than } 16 \\
\text { Years }\end{array}$ & 64 & 0.29 & 0.40 & 1 & 0.13 & 0.63 & 24 & 0.34 & 0.44 & 39 & 0.26 & 0.36 \\
\hline All Households & 450 & 0.40 & $\$ 0.52$ & 60 & 0.38 & $\$ 0.54$ & 207 & 0.43 & $\$ 0.54$ & 183 & 0.37 & $\$ 0.50$ \\
\hline
\end{tabular}


TABLE 13

POULTRY: The Weekly Per Capita Consumption and the Average Price Paid

Per Pound by Households Relative to the Occupation of the Principal Income Earner, Summer, 1973.

\begin{tabular}{|c|c|c|c|c|c|c|c|c|c|c|c|c|}
\hline \multirow{2}{*}{$\begin{array}{l}\text { Occupation of the } \\
\text { Principal } \\
\text { Income } \\
\text { Earner }\end{array}$} & \multicolumn{3}{|c|}{ STATE } & \multicolumn{3}{|c|}{ RURAL } & \multicolumn{3}{|c|}{ MIDDLE } & \multicolumn{3}{|c|}{ URBAN } \\
\hline & Responses & Lbs. & Price & Responses & Lbs. & Price & Responses & Lbs. & Price & Responses & Lbs. & Price \\
\hline Farmer & 15 & 0.54 & $\$ 0.46$ & 9 & 0.49 & $\$ 0.56$ & 6 & 0.62 & $\$ 0.30$ & \multicolumn{3}{|c|}{ Unidentified } \\
\hline Professional & 83 & 0.66 & 0.67 & 3 & 0.67 & 0.83 & 28 & 0.69 & 0.72 & 52 & 0.65 & $\$ 0.64$ \\
\hline Housewife & 10 & 1.20 & 1.35 & 4 & 1.00 & 1.00 & 4 & 1.25 & 1.63 & 2 & 1.50 & 1.50 \\
\hline Laborer & 72 & 0.58 & 0.58 & 12 & 0.76 & 0.70 & 41 & 0.53 & 0.53 & 19 & 0.59 & 0.60 \\
\hline Self Employed & 40 & 0.70 & 0.75 & 5 & 1.00 & 0.93 & 16 & 0.61 & 0.64 & 19 & 0.70 & 0.80 \\
\hline Retired & 75 & 0.88 & 0.97 & 11 & 1.09 & 1.13 & 39 & 0.95 & 0.92 & 25 & 0.69 & 0.99 \\
\hline Unemployed & 5 & 0.90 & 1.05 & 1 & 0.88 & 1.13 & 2 & 1.00 & 1.00 & 2 & 0.81 & 1.06 \\
\hline White Collar & 50 & 0.54 & 0.58 & 2 & 0.50 & 0.83 & 17 & 0.74 & 0.66 & 31 & 0.43 & 0.53 \\
\hline Service Worker & 18 & 0.69 & 0.81 & 1 & 0.70 & 0.90 & 10 & 0.71 & 0.77 & 7 & 0.67 & 0.84 \\
\hline Craftsman & 24 & 0.77 & 0.71 & 4 & 0.60 & 0.37 & 8 & 0.82 & 0.80 & 12 & 0.80 & 0.76 \\
\hline Machine Operator & 37 & 0.75 & 0.80 & 7 & 1.39 & 1.50 & 26 & 0.58 & 0.61 & 4 & 0.78 & 0.82 \\
\hline \multicolumn{13}{|l|}{ Sales and } \\
\hline Clerical & 21 & 0.67 & 1.00 & 1 & 0.25 & 0.75 & 10 & 0.69 & 0.85 & 10 & 0.69 & 1.17 \\
\hline All Households & 450 & 0.70 & $\$ 0.75$ & 60 & 0.86 & $\$ 0.89$ & 207 & 0.71 & $\$ 0.71$ & 183 & 0.64 & 0.74 \\
\hline
\end{tabular}


TABLE 14

SEAFOOD: The Weekly Per Capita Consumption and the Average Price Paid Per

Pound by Households Relative to the Occupation of the Principal Income Earner, Summer, 1973.

\begin{tabular}{|c|c|c|c|c|c|c|c|c|c|c|c|c|}
\hline \multirow{2}{*}{$\begin{array}{l}\text { Occupation of } \\
\text { the Principal } \\
\text { Income } \\
\text { Earner }\end{array}$} & \multicolumn{3}{|c|}{ STATE } & \multicolumn{3}{|c|}{ RURAL } & \multicolumn{3}{|c|}{ MIDDLE } & \multicolumn{3}{|c|}{ URBAN } \\
\hline & Responses & Lbs. & Price & Responses & Lbs. & Price & Responses & Lbs. & Price & Responses & Lbs. & Price \\
\hline Farmer & 15 & 0.20 & $\$ 0.25$ & 9 & 0.22 & $\$ 0.30$ & 6 & 0.17 & $\$ 0.17$ & \multicolumn{3}{|c|}{ Unidentified } \\
\hline Professional & 83 & 0.30 & 0.37 & 3 & 0.42 & 0.69 & 28 & 0.31 & 0.35 & 52 & 0.28 & $\$ 0.36$ \\
\hline Housewife & 10 & 0.28 & 0.34 & 4 & 0.40 & 0.54 & 4 & 0.31 & 0.31 & 2 & 0.00 & 0.00 \\
\hline Laborer & 72 & 0.21 & 0.29 & 12 & 0.11 & 0.18 & 41 & 0.25 & 0.34 & 19 & 0.20 & 0.26 \\
\hline Self Employed & 40 & 0.17 & 0.27 & 5 & 0.17 & 0.26 & 16 & 0.23 & 0.38 & 19 & 0.12 & 0.19 \\
\hline Retired & 75 & 0.28 & 0.32 & 11 & 0.44 & 0.51 & 39 & 0.22 & 0.29 & 25 & 0.30 & 0.27 \\
\hline Unemployed & 5 & 0.45 & 0.45 & 1 & 0.00 & 0.00 & 2 & 0.75 & 0.75 & 2 & 0.38 & 0.38 \\
\hline White Collar & 50 & 0.31 & 0.39 & 2 & 0.33 & 0.50 & 17 & 0.26 & 0.34 & 31 & 0.34 & 0.40 \\
\hline Service Worker & 18 & 0.29 & 0.38 & 1 & 0.00 & 0.00 & 10 & 0.27 & 0.37 & 7 & 0.35 & 0.46 \\
\hline Craftsman & 24 & 0.24 & 0.28 & 4 & 0.09 & 0.09 & 8 & 0.42 & 0.46 & 12 & 0.17 & 0.24 \\
\hline Machine Operator & 37 & 0.31 & 0.38 & 7 & 0.21 & 0.30 & 26 & 0.32 & 0.41 & 4 & 0.38 & 0.39 \\
\hline \multicolumn{13}{|l|}{ Sales and } \\
\hline Clerical & 21 & 0.32 & 0.45 & 1 & 0.75 & 1.25 & 10 & 0.37 & 0.42 & 10 & 0.24 & 0.40 \\
\hline All Households & 450 & 0.27 & $\$ 0.34$ & 60 & 0.25 & $\$ 0.34$ & 207 & 0.28 & $\$ 0.35$ & 183 & 0.26 & $\$ 0.32$ \\
\hline
\end{tabular}


TABLE 15

LUNCH MEAT: The Weekly Per Capita Consumption and the Average Price Paid Per

Pound by Households Relative to the Occupation of the Principal Income Earner, Summer, 1973.

\begin{tabular}{|c|c|c|c|c|c|c|c|c|c|c|c|c|}
\hline \multirow{2}{*}{$\begin{array}{l}\text { Occupation of } \\
\text { the Principal } \\
\text { Income } \\
\text { Earner }\end{array}$} & \multicolumn{3}{|c|}{ STATE } & \multicolumn{3}{|c|}{ RURAL } & \multicolumn{3}{|c|}{ MIDDLE } & \multicolumn{3}{|c|}{ URBAN } \\
\hline & Responses & Lbs. & Price & Responses & Lbs. & Price & Responses & Lbs. & Price & Responses & Lbs. & Price \\
\hline Farmer & 15 & 0.31 & $\$ 0.29$ & 9 & 0.32 & $\$ 0.34$ & 6 & 0.30 & $\$ 0.22$ & \multicolumn{3}{|c|}{ Unidentified } \\
\hline Professional & 83 & 0.36 & 0.47 & 3 & 0.50 & 0.61 & 28 & 0.34 & 0.45 & 52 & 0.36 & $\$ 0.47$ \\
\hline Housewife & 10 & 0.66 & 0.66 & 4 & 0.65 & 0.65 & 4 & 0.88 & 0.88 & 2 & 0.25 & 0.25 \\
\hline Laborer & 72 & 0.47 & 0.59 & 12 & 0.44 & 0.59 & 41 & 0.57 & 0.68 & 19 & 0.26 & 0.40 \\
\hline Self Employed & 40 & 0.33 & 0.49 & 5 & 0.22 & 0.37 & 16 & 0.32 & 0.46 & 19 & 0.37 & 0.55 \\
\hline Retired & 75 & 0.30 & 0.41 & 11 & 0.09 & 0.17 & 39 & 0.35 & 0.46 & 25 & 0.31 & 0.45 \\
\hline Unemployed & 5 & 0.47 & 0.52 & 1 & 0.38 & 0.38 & 2 & 0.67 & 0.67 & 2 & 0.31 & 0.44 \\
\hline White Collar & 50 & 0.35 & 0.42 & 2 & 0.17 & 0.17 & 17 & 0.31 & 0.39 & 31 & 0.39 & 0.45 \\
\hline Service Worker & 18 & 0.46 & 0.66 & 1 & 0.90 & 1.50 & 10 & 0.45 & 0.63 & 7 & 0.42 & 0.59 \\
\hline Craftsman & 24 & 0.45 & 0.58 & 4 & 0.38 & 0.47 & 8 & 0.78 & 0.79 & 12 & 0.26 & 0.47 \\
\hline Machine Operator & 37 & 0.46 & 0.66 & 7 & 0.73 & 1.29 & 26 & 0.39 & 0.52 & 4 & 0.42 & 0.40 \\
\hline \multicolumn{13}{|l|}{ Sales and } \\
\hline Clerical & 21 & 0.66 & 0.92 & 1 & 0.25 & 0.75 & 10 & 0.44 & 0.69 & 10 & 0.92 & 1.17 \\
\hline All Households & 450 & 0.40 & $\$ 0.52$ & 60 & 0.38 & $\$ 0.54$ & 207 & 0.43 & $\$ 0.54$ & 183 & 0.37 & $\$ 0.50$ \\
\hline
\end{tabular}


TABLE 16

POULTRY: The Weekly Per Capita Consumption and the Average Price Paid

Per Pound by Household Size, Summer, 1973.

\begin{tabular}{|c|c|c|c|c|c|c|c|c|c|c|c|c|}
\hline \multirow{2}{*}{$\begin{array}{l}\text { |Household } \\
\text {,Size }\end{array}$} & \multicolumn{3}{|c|}{ STATE } & \multicolumn{3}{|c|}{ RURAL } & \multicolumn{3}{|c|}{ MIDDLE } & \multicolumn{3}{|c|}{ URBAN } \\
\hline & Responses & Lbs. & Price & Responses & Lbs. & Price & Responses & Lbs. & Price & Responses & Lbs. & Price \\
\hline 1 & 40 & 0.96 & $\$ 1.33$ & 5 & 1.10 & $\$ 1.40$ & 17 & 1.15 & $\$ 1.03$ & 18 & 0.75 & $\$ 1.58$ \\
\hline 2 & 146 & 0.82 & 0.88 & 15 & 1.07 & 1.17 & 66 & 0.92 & 0.98 & 65 & 0.65 & 0.70 \\
\hline 3 & 92 & 0.68 & 0.68 & 13 & 0.82 & 0.74 & 46 & 0.64 & 0.63 & 33 & 0.69 & 0.73 \\
\hline 4 & 97 & 0.53 & 0.55 & 14 & 0.64 & 0.70 & 40 & 0.44 & 0.47 & 43 & 0.58 & 0.58 \\
\hline 5 & 46 & 0.60 & 0.55 & 8 & 0.90 & 0.74 & 22 & 0.51 & 0.51 & 16 & 0.56 & 0.53 \\
\hline 6 & 14 & 0.53 & 0.52 & 2 & 0.29 & 0.29 & 7 & 0.42 & 0.39 & 5 & 0.78 & 0.78 \\
\hline 7 & 10 & 0.71 & 0.69 & 1 & 2.14 & 2.14 & 7 & 0.62 & 0.58 & 2 & 0.32 & 0.32 \\
\hline 8 & 3 & 0.25 & 0.21 & 1 & 0.31 & 0.56 & 1 & 0.00 & 0.00 & 1 & 0.44 & 0.06 \\
\hline 9 & 1 & 0.17 & 0.28 & 1 & 0.17 & 0.28 & \multicolumn{3}{|c|}{ Unidentified } & \multirow{2}{*}{\multicolumn{3}{|c|}{$\begin{array}{l}\text { Unidentified } \\
\text { Unidentified }\end{array}$}} \\
\hline 10 & 1 & 0.25 & 0.25 & \multicolumn{3}{|c|}{ Unidentified } & 1 & 0.25 & 0.25 & & & \\
\hline All Households & 450 & 0.70 & $\$ 0.75$ & 60 & 0.86 & 89 & 207 & 0.71 & $\$ 0.71$ & \multicolumn{3}{|c|}{$0.64 \$ 0.74$} \\
\hline
\end{tabular}


TABLE 17

SEAFOOD: The Weekly Per Capita Consumption and the Average Price Paid Per

Pound by Household Size, Summer, 1973.

\begin{tabular}{|c|c|c|c|c|c|c|c|c|c|c|c|c|}
\hline \multirow{2}{*}{$\begin{array}{l}\text { Household } \\
\text { Size }\end{array}$} & \multicolumn{3}{|c|}{ STATE } & \multicolumn{3}{|c|}{ RURAL } & \multicolumn{3}{|c|}{ MIDDLE } & \multicolumn{3}{|c|}{ URBAN } \\
\hline & Responses & Lbs. & Price & Responses & Lbs. & Price & Responses & Lbs. & Price & Responses & Lbs. & Price \\
\hline 1 & 40 & 0.26 & $\$ 0.31$ & 5 & 0.20 & $\$ 0.20$ & 17 & 0.35 & $\$ 0.35$ & 18 & 0.19 & $\$ 0.31$ \\
\hline 2 & 146 & 0.35 & 0.43 & 15 & 0.38 & 0.48 & 66 & 0.36 & 0.47 & 65 & 0.33 & 0.38 \\
\hline 3 & 92 & 0.29 & 0.40 & 13 & 0.23 & 0.36 & 46 & 0.32 & 0.42 & 33 & 0.27 & 0.38 \\
\hline 4 & 97 & 0.18 & 0.24 & 14 & 0.26 & 0.35 & 40 & 0.18 & 0.22 & 43 & 0.16 & 0.23 \\
\hline 5 & 46 & 0.20 & 0.23 & 8 & 0.13 & 0.18 & 22 & 0.17 & 0.20 & 16 & 0.29 & 0.28 \\
\hline 6 & 14 & 0.20 & 0.17 & 2 & 0.13 & 0.13 & 7 & 0.18 & 0.23 & 5 & 0.25 & 0.12 \\
\hline 7 & 10 & 0.23 & 0.34 & 1 & 0.21 & 0.79 & 7 & 0.15 & 0.19 & 2 & 0.50 & 0.64 \\
\hline 8 & 3 & 0.21 & 0.17 & 1 & 0.31 & 0.44 & 1 & 0.00 & 0.00 & 1 & 0.31 & 0.06 \\
\hline 9 & 1 & 0.00 & 0.00 & 1 & 0.00 & 0.00 & \multicolumn{3}{|c|}{ Unidentified } & \multirow{2}{*}{\multicolumn{3}{|c|}{$\begin{array}{l}\text { Unidentified } \\
\text { Unidentified }\end{array}$}} \\
\hline 10 & 1 & 0.25 & 0.25 & \multicolumn{3}{|c|}{ Unidentified } & 1 & 0.25 & 0.25 & & & \\
\hline All Households & 450 & 0.27 & $\$ 0.34$ & 60 & 0.25 & $\$ 0.34$ & 207 & 0.28 & $\$ 0.35$ & \multicolumn{3}{|c|}{$\begin{array}{llll} & & & \\
183 & 0.26 & \$ 0.32\end{array}$} \\
\hline
\end{tabular}




\section{TABLE 18}

LUNCH MEAT: The Weekly Per Capita Consumption and the Average Price Paid Per Pound by Household Size, Summer, 1973.

\begin{tabular}{|c|c|c|c|c|c|c|c|c|c|c|c|c|}
\hline \multirow{2}{*}{$\begin{array}{l}\text { Household } \\
\text { Size }\end{array}$} & \multicolumn{3}{|c|}{ STATE } & \multicolumn{3}{|c|}{ RURAL } & \multicolumn{3}{|c|}{ MIDDLE } & \multicolumn{3}{|c|}{ URBAN } \\
\hline & Responses & Lbs. & Price & Responses & Lbs. & Price & Responses & Lbs. & Price & Responses & Lbs. & Price \\
\hline 1 & 40 & 0.65 & $\$ 0.88$ & 5 & 0.80 & $\$ 1.20$ & 17 & 0.59 & $\$ 0.71$ & 18 & 0.67 & $\$ 0.94$ \\
\hline 2 & 146 & 0.34 & 0.44 & 15 & 0.15 & 0.25 & 66 & 0.34 & 0.43 & 65 & 0.37 & 0.50 \\
\hline 3 & 92 & 0.37 & 0.51 & 13 & 0.41 & 0.69 & 46 & 0.37 & 0.51 & 33 & 0.34 & 0.44 \\
\hline 4 & 97 & 0.34 & 0.45 & 14 & 0.33 & 0.42 & 40 & 0.38 & 0.51 & 43 & 0.30 & 0.41 \\
\hline 5 & 46 & 0.51 & 0.62 & 8 & 0.44 & 0.54 & 22 & 0.61 & 0.74 & 16 & 0.39 & 0.49 \\
\hline 6 & 14 & 0.52 & 0.61 & 2 & 0.21 & 0.13 & 7 & 0.83 & 0.93 & 5 & 0.22 & 0.35 \\
\hline 7 & 10 & 0.51 & 0.60 & 1 & 1.71 & 1.71 & 7 & 0.40 & 0.50 & 2 & 0.32 & 0.39 \\
\hline 8 & 3 & 0.44 & 0.44 & 1 & 0.56 & 0.81 & 1 & 0.44 & 0.44 & 1 & 0.31 & 0.06 \\
\hline 9 & 1 & 0.50 & 0.50 & 1 & 0.50 & 0.50 & \multicolumn{3}{|c|}{ Unidentified } & \multirow{2}{*}{\multicolumn{3}{|c|}{$\begin{array}{l}\text { Unidentified } \\
\text { Unidentified }\end{array}$}} \\
\hline 10 & 1 & 0.65 & 0.65 & \multicolumn{3}{|c|}{ Unidentified } & 1 & 0.65 & 0.65 & & & \\
\hline All Households & 450 & 0.50 & $\$ 0.52$ & 60 & 0.38 & $\$ 0.54$ & 207 & 0.43 & $\$ 0.54$ & \multicolumn{3}{|c|}{$0.37 \$ 0.50$} \\
\hline
\end{tabular}




\section{TABLE 19}

POULTRY: The Weekly Per Capita Consumption and the Average Price Paid

Per Pound by the Total Annual Household Income, Summer, 1973.

\begin{tabular}{|c|c|c|c|c|c|c|c|c|c|c|c|c|}
\hline \multirow{2}{*}{$\begin{array}{l}\text { Total Annual } \\
\text { Household } \\
\text { Income } \\
\end{array}$} & \multicolumn{3}{|c|}{ STATE } & \multicolumn{3}{|c|}{ RURAL } & \multicolumn{3}{|c|}{ MIDDLE } & \multicolumn{3}{|c|}{ URBAN } \\
\hline & Responses & Lbs. & Price & Responses & Lbs. & Price & Responses & Lbs. & Price & Responses & Lbs. & Price \\
\hline Under $\$ 1,000$ & 13 & 0.39 & $\$ 0.41$ & 1 & 0.13 & $\$ 0.13$ & 9 & 0.41 & $\$ 0.44$ & 3 & 0.42 & $\$ 0.42$ \\
\hline$\$ 1,00-\$ 4,999$ & 80 & 0.75 & 0.79 & 22 & 0.78 & 0.77 & 37 & 0.85 & 0.85 & 21 & 0.55 & 0.72 \\
\hline$\$ 5,000-\$ 9,999$ & 138 & 0.77 & 0.88 & 22 & 1.11 & 1.16 & 65 & 0.64 & 0.65 & 51 & 0.79 & 1.04 \\
\hline$\$ 10,000-\$ 14,999$ & 114 & 0.66 & 0.67 & 9 & 0.38 & 0.48 & 60 & 0.73 & 0.69 & 45 & 0.62 & 0.64 \\
\hline$\$ 15,000-\$ 24,999$ & 76 & 0.66 & 0.71 & 6 & 1.07 & 1.10 & 31 & 0.68 & 0.79 & 39 & 0.59 & 0.60 \\
\hline$\$ 25,000$ and over & 27 & 0.65 & 0.65 & \multicolumn{3}{|c|}{ Unidentified } & 4 & 1.08 & 1.00 & 23 & 0.58 & 0.59 \\
\hline Unidentified & 2 & 0.53 & 0.73 & \multicolumn{3}{|c|}{ Unidentified } & 1 & 0.30 & 0.70 & 1 & 0.75 & 0.75 \\
\hline All Households & 450 & 0.70 & .75 & 60 & 0.86 & $\$ 0.89$ & 207 & 0.71 & $\$ 0.71$ & 183 & 0.64 & 0.74 \\
\hline
\end{tabular}


TABLE 20

SEAFOOD: The Weekly Per Capita Consumption and the Average Price Paid Per Pound by the Total Annual Household Income, Summer, 1973.

\begin{tabular}{|c|c|c|c|c|c|c|c|c|c|c|c|c|}
\hline \multirow{2}{*}{$\begin{array}{l}\text { Total Annual } \\
\text { Household } \\
\text { Income }\end{array}$} & \multicolumn{3}{|c|}{ STATE } & \multicolumn{3}{|c|}{ RURAL } & \multicolumn{3}{|c|}{ MIDDLE } & \multicolumn{3}{|c|}{ URBAN } \\
\hline & Responses & Lbs. & Price & Responses & Lbs. & Price & Responses & Lbs. & Price & Responses & Lbs. & Price \\
\hline Under $\$ 1,000$ & 13 & 0.11 & $\$ 0.11$ & 1 & 0.63 & $\$ 0.63$ & 9 & 0.09 & $\$ 0.09$ & 3 & 0.00 & $\$ 0.00$ \\
\hline$\$ 1,000-\$ 4,999$ & 80 & 0.22 & 0.24 & 22 & 0.22 & 0.30 & 37 & 0.15 & 0.18 & 21 & 0.35 & 0.31 \\
\hline$\$ 5,000-\$ 9,999$ & 138 & 0.28 & 0.33 & 22 & 0.27 & 0.39 & 65 & 0.30 & 0.38 & 51 & 0.25 & 0.26 \\
\hline$\$ 10,000-\$ 14,999$ & 114 & 0.25 & 0.33 & 9 & 0.08 & 0.19 & 60 & 0.31 & 0.38 & 45 & 0.20 & 0.28 \\
\hline$\$ 15,000-\$ 24,999$ & 76 & 0.33 & 0.43 & 6 & 0.50 & 0.56 & 31 & 0.37 & 0.49 & 39 & 0.27 & 0.36 \\
\hline$\$ 25,000$ and Over & 27 & 0.36 & 0.52 & \multicolumn{3}{|c|}{ Unidentified } & 4 & 0.54 & 0.67 & 23 & 0.33 & 0.50 \\
\hline Unidentified & 2 & 0.38 & 0.38 & \multicolumn{3}{|c|}{ Unidentified } & 1 & 0.00 & 0.00 & 1 & 0.75 & 0.75 \\
\hline All Households & 450 & 0.27 & $\$ 0.34$ & 60 & 0.25 & $\$ 0.34$ & 207 & 0.28 & $\$ 0.35$ & 183 & 0.26 & $\$ 0.32$ \\
\hline
\end{tabular}


TABLE 21

LUNCH MEAT: The Weekly Per Capita Consumption and the Average Price Paid Per

Pound by the Total Annual Household Income, Summer, 1973.

\begin{tabular}{|c|c|c|c|c|c|c|c|c|c|c|c|c|}
\hline \multirow{2}{*}{$\begin{array}{l}\text { Total Annual } \\
\text { Household } \\
\text { Income }\end{array}$} & \multicolumn{3}{|c|}{ STATE } & \multicolumn{3}{|c|}{ RURAL } & \multicolumn{3}{|c|}{ MIDDLE } & \multicolumn{3}{|c|}{ URBAN } \\
\hline & Responses & Lbs. & Price & Responses & Lbs. & Price & Responses & Lbs. & Price & Responses & Lbs. & Price \\
\hline Under $\$ 1,000$ & 13 & 0.42 & $\$ 0.50$ & 1 & 0.88 & $\$ 0.88$ & 9 & 0.37 & $\$ 0.48$ & 3 & 0.42 & $\$ 0.42$ \\
\hline$\$ 1,000-\$ 4,999$ & 80 & 0.41 & 0.50 & 22 & 0.30 & 0.38 & 37 & 0.43 & 0.52 & 21 & 0.49 & 0.57 \\
\hline$\$ 5,000-\$ 9,999$ & 138 & 0.44 & 0.56 & 22 & 0.52 & 0.71 & 65 & 0.39 & 0.49 & 51 & 0.46 & 0.58 \\
\hline$\$ 10,000-\$ 14,999$ & 114 & 0.39 & 0.51 & 9 & 0.26 & 0.50 & 60 & 0.47 & 0.59 & 45 & 0.31 & 0.41 \\
\hline$\$ 15,000-\$ 24,999$ & 76 & 0.37 & 0.55 & 6 & 0.28 & 0.47 & 31 & 0.43 & 0.59 & 39 & 0.34 & 0.53 \\
\hline$\$ 25,000$ and Over & 27 & 0.33 & 0.44 & \multicolumn{3}{|c|}{ Unidentified } & 4 & 0.67 & 0.54 & 23 & 0.27 & 0.42 \\
\hline Unidentified & 2 & 0.15 & 0.15 & \multicolumn{3}{|c|}{ Unidentified } & 1 & 0.30 & 0.30 & 1 & 0.00 & 0.00 \\
\hline All Households & 450 & 0.40 & $\$ 0.52$ & 60 & 0.38 & $\$ 0.54$ & 207 & 0.43 & $\$ 0.54$ & 183 & 0.37 & $\$ 0.50$ \\
\hline
\end{tabular}


TABLE 22

Results of Weekly Per Capita Poultry Consumption ( $\left.\mathrm{Y}_{3}\right)$ Multiple Regression, Summer, 1973.

\begin{tabular}{|c|c|c|c|c|}
\hline Variable & $\begin{array}{l}\text { Regression } \\
\text { Coefficient }\end{array}$ & $\begin{array}{c}\mathbf{t} \\
\text { Values }\end{array}$ & $\begin{array}{l}\text { Standard } \\
\text { Error of } \\
\text { Regression } \\
\text { Coefficient } \\
\end{array}$ & $\begin{array}{c}\text { Standard } \\
\text { B } \\
\text { Values } \\
\end{array}$ \\
\hline $\mathrm{X}_{1}$ County Classification Group & 0.4579 & $3.2135^{* *}$ & 0.1425 & 0.2524 \\
\hline $\begin{array}{ll}X_{2} & \text { Family Member Most } \\
\text { Responsible for Meat } \\
\text { Purchasing "Single" }\end{array}$ & 0.7710 & $3.0707^{* *}$ & 0.2511 & 0.3035 \\
\hline $\begin{array}{l}\mathrm{X}_{4} \text { Age of the Principal } \\
\text { Income Earner }\end{array}$ & 0.0762 & $2.1447^{* * *}$ & 0.0355 & 0.1751 \\
\hline$X_{5}$ Education of the Principal & -0.4735 & $-2.3633^{* * *}$ & 0.2003 & -0.2507 \\
\hline $\mathrm{X}_{6}$ Occupation of the Principal & 0.3368 & $1.6905^{* * * *}$ & 0.1992 & 0.1622 \\
\hline$x_{7}$ Household Size & -0.0849 & $-2.9586^{* *}$ & 0.0286 & -0.2218 \\
\hline $\mathrm{X}_{i 1}$ Price of Poultry & -0.2259 & $-3.6095^{*}$ & 0.0626 & -0.2776 \\
\hline $\begin{aligned} \mathrm{R}^{2} & =0.3167 \quad \mathrm{~F}=2.5420 \\
* & =0.001 \text { Significance Level } \\
* * * & =0.01 \text { Significance Level } \\
* * * & =0.05 \text { Significance Level } \\
* * * * & =0.10 \text { Significance Level }\end{aligned}$ & greater $\mathrm{F}=\mathrm{C}$ & & & \\
\hline
\end{tabular}


TABLE 23

Results of Weekly Per Capita Seafood Consumption $\left(\mathrm{Y}_{4}\right)$ Multiple Regression, Summer, 1973.

\begin{tabular}{|c|c|c|c|c|}
\hline Variable & $\begin{array}{l}\text { Regression } \\
\text { Coefficient }\end{array}$ & $\begin{array}{c}\mathbf{t} \\
\text { Values }\end{array}$ & $\begin{array}{c}\text { Standard } \\
\text { Error of } \\
\text { Regression } \\
\text { Coefficient }\end{array}$ & $\begin{array}{c}\text { Standard } \\
\text { B } \\
\text { Values } \\
\end{array}$ \\
\hline \multicolumn{5}{|l|}{$\begin{array}{l}X_{2} \text { Family Member Most Respon- } \\
\text { sible for Meat Purchasing }\end{array}$} \\
\hline "Single" & 0.3717 & $2.1855^{* * *}$ & 0.1701 & 0.2182 \\
\hline \multicolumn{5}{|l|}{$\mathrm{X}_{5}$ Education of the Principal } \\
\hline "0 to 7 Years" & -0.4109 & $-2.2542^{* * *}$ & 0.1823 & -0.1944 \\
\hline "8 Years (grade school graduate)" & -0.2701 & $-1.9905^{* * *}$ & 0.1357 & -0.2133 \\
\hline "12 Years (high school graduate)" & -0.1820 & $-1.7170^{* * * *}$ & 0.1060 & -0.2233 \\
\hline "13 to 15 Years" & -0.1738 & $-1.6958^{* * * *}$ & 0.1025 & -0.1662 \\
\hline$X_{7}$ Household Size & -0.0615 & $-3.1675^{* *}$ & 0.0194 & -0.2398 \\
\hline$x_{12}^{\prime}$ Price of Seafood & -0.0886 & $-2.9777^{* *}$ & 0.0298 & -0.2099 \\
\hline
\end{tabular}

$\mathrm{R}^{2}=0.3030 \quad \mathrm{~F}=\mathbf{2 . 3 8 4 4} \quad$ Probability of a greater $\mathrm{F}=0.0004$

$* *=0.01$ Significance Level

$* * *=0.05$ Significance Level

$* * * *=0.10$ Significance Level 
TABLE 24

Results of Weekly Per Capita Lunch Meat Consumption $\left(Y_{5}\right)$ Multiple Regression, Summer, 1973.

\begin{tabular}{|c|c|c|c|c|}
\hline Variable & $\begin{array}{l}\text { Regression } \\
\text { Coefficient } \\
\end{array}$ & $\begin{array}{c}\mathbf{t} \\
\text { Values } \\
\end{array}$ & $\begin{array}{l}\text { Standard } \\
\text { Error or } \\
\text { Regression } \\
\text { Coefficient }\end{array}$ & $\begin{array}{c}\text { Standard } \\
\text { B } \\
\text { Values } \\
\end{array}$ \\
\hline \multicolumn{5}{|c|}{$\begin{array}{l}\mathrm{X}_{2} \begin{array}{l}\text { Family Member Most Res } \\
\text { sible for Meat Purchasing }\end{array}\end{array}$} \\
\hline "Single" & 0.7089 & $4.1972^{*}$ & 0.1689 & 0.3860 \\
\hline \multicolumn{5}{|c|}{$X_{5}$ Education of the Principal } \\
\hline "0 to 7 Years" & 0.4167 & $2.3022^{* * *}$ & 0.1810 & 0.1829 \\
\hline \multicolumn{5}{|c|}{$\mathrm{X}_{6}$ Occupation of the Principal } \\
\hline "Professional" & -0.2480 & $-1.9280^{* * * *}$ & 0.1287 & -0.2253 \\
\hline "Unemployed" & -0.7269 & $-2.5683^{* * *}$ & 0.2830 & -0.1727 \\
\hline "White Collar" & -0.3021 & $-2.4110^{* * *}$ & 0.1253 & -0.2647 \\
\hline$x_{9}$ Price of Beef & 0.1447 & $3.5401^{*}$ & 0.0409 & 0.2511 \\
\hline$x_{13}$ Price of Lunch Meat & -0.1392 & $-4.1738^{*}$ & 0.0334 & -0.2684 \\
\hline
\end{tabular}

$R^{2}=0.4086 \quad F=3.7883 \quad$ Probability of a greater $F=0.0001$

$*=0.001$ Significance Level

$* *=0.01$ Significance Level

$* * *=0.05$ Significance Level

$* * * * 0.10$ Significance Level 


\section{LITERATURE CITED}

New York State Division of Housing, A Method for Employing Sampling Techniques in Housing Surveys, New York: New York State Division of Housing, September, 1948.

U. S. Department of Commerce, 1970 Census of Population: Number of Inhabitants, West Virginia, Bureau of the Census, Washington: U. S. Government Printing Office, May, 1971.

U. S. Department of Commerce, Statistical Abstract of the United States, 1973, Social and Economic Statistics Administration, Bureau of the Census, Washington: U. S. Government Printing Office, July, 1973. 
APPENDIX TABLE 1

Number of Responses and Per Cent of Households Responding by Socioeconomic

Characteristic, Summer, 1973

\begin{tabular}{|c|c|c|c|c|c|c|c|c|}
\hline \multirow{2}{*}{$\begin{array}{c}\text { Socioeconomic } \\
\text { Category }\end{array}$} & \multicolumn{8}{|c|}{ Responses and Per Cent of Households Responding } \\
\hline & \multicolumn{2}{|c|}{ STATE } & \multicolumn{2}{|c|}{ RURAL } & \multicolumn{2}{|c|}{ MIDDLE } & \multicolumn{2}{|c|}{ URBAN } \\
\hline $\begin{array}{l}\text { Family Member } \\
\text { Most Responsible } \\
\text { for Meat Purchasing }\end{array}$ & Responses & Per Cent & Responses & Per Cent & Responses & Per Cent & Responses & Per Cent \\
\hline Wife & 322 & 71.56 & 45 & 75.00 & 151 & 72.95 & 126 & 68.85 \\
\hline Husband & 69 & 15.33 & 10 & 16.67 & 31 & 14.98 & 28 & 15.30 \\
\hline Single & 39 & 8.67 & 4 & 6.67 & 18 & 8.70 & 17 & 9.29 \\
\hline Both Wife and Husband & 20 & 4.44 & 1 & 1.67 & 7 & 3.38 & 12 & 6.56 \\
\hline TOTAL & 450 & 100.00 & 60 & 100.01 & 207 & 100.01 & 183 & 100.00 \\
\hline \multicolumn{9}{|l|}{$\begin{array}{l}\text { Principal Income } \\
\text { Earner }\end{array}$} \\
\hline Wife & 33 & 7.33 & 5 & 8.33 & 13 & 6.28 & 15 & 8.20 \\
\hline Husband & 378 & 84.00 & 51 & 85.00 & 176 & 85.02 & 151 & 82.51 \\
\hline Single & 39 & 8.67 & 4 & 6.67 & 18 & 8.70 & 17 & 9.29 \\
\hline TOTAL & 450 & 100.00 & 60 & 100.00 & 207 & 100.00 & 183 & 100.00 \\
\hline
\end{tabular}

${ }^{a}$ Rounding errors may cause per cent totals to not equal 100.00 per cent. 
Table 1 (continued)

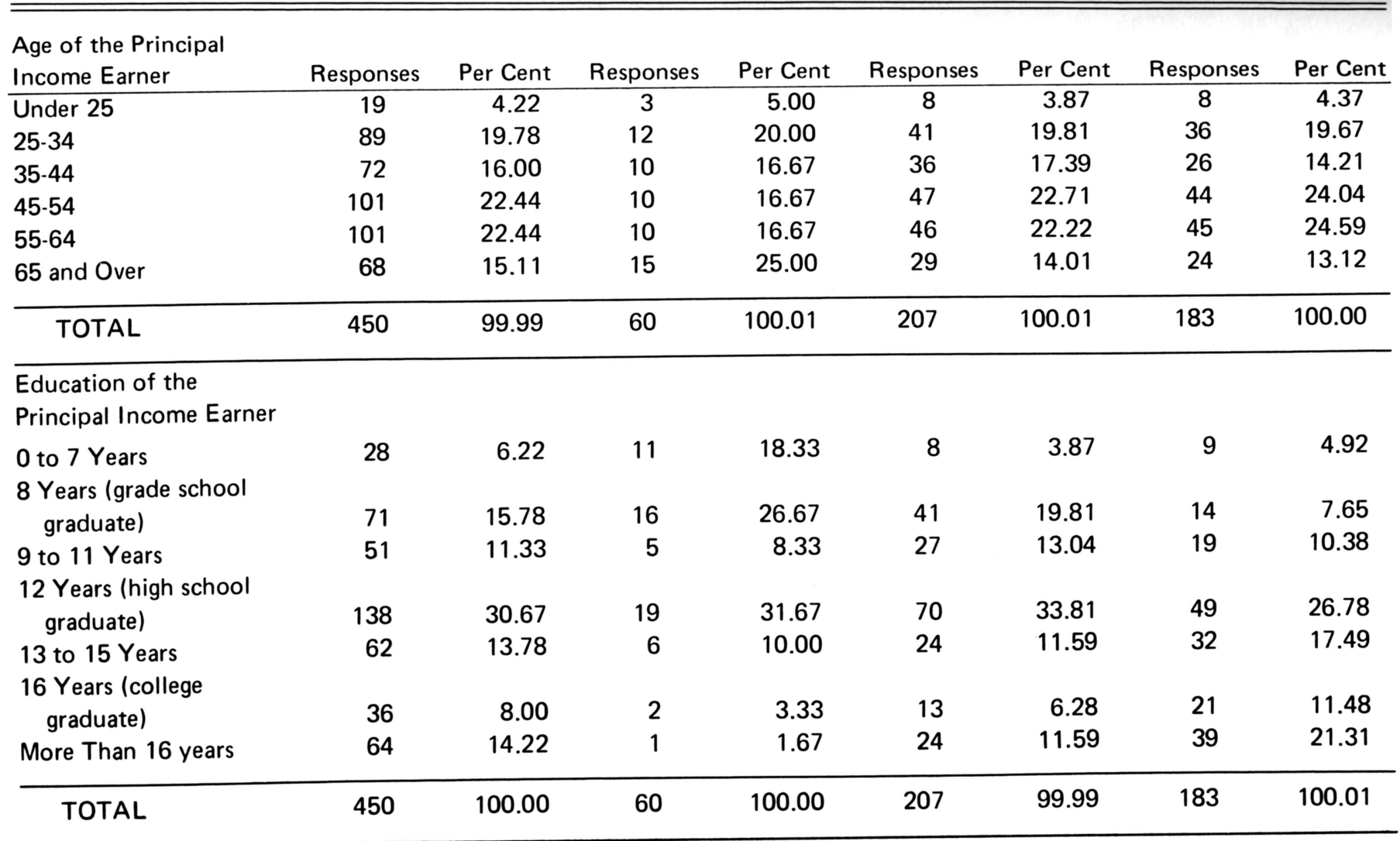

${ }^{a}$ Rounding errors may cause per cent totals to not equal 100.00 per cent. 
Occupation of the

Principal Income

Earner

Responses

Per Cent

Responses

Per Cent

Responses

Per Cent

Responses Per Cent

Farmer

Professional

Housewife

18.44

9

15.00

5.00

6.67

20.00

Laborer

2.22

$72 \quad 16.00$

Self-Employed

$40 \quad 8.89$

8.33

18.33

16.67

Unemployed

75

White Collar

5

1.11

1.67

3.33

11.11

1.67

4.00

6.67

11.67

8.22

1.67

$28 \quad 13.53$

13.53

1.93

19.81

7.73

18.84

0.97

8.21

4.83

3.87

12.56

4.83

$\begin{array}{rr}0 & 0.00 \\ 52 & 28.41 \\ 2 & 1.09\end{array}$

$37 \quad 8.22$

7

8

26

19

10.38

Sales and Clerical

21

$450 \quad 99.99$

60

100.01

207

100.00

\section{Size of Household}

$\begin{array}{ll}1 & 1 \\ 2 & 2\end{array}$

40

8.89

8.33

17

8.21

18

9.84

33

146

32.44

25.00

66

31.88

65

35.52

44

92

20.44

21.67

22.22

33

23.33

21.56

46

10.22

13.33

46

19.32

10.63

14

3.11

3.33

22

3.38

43

18.03

23.50

8
2

7

16

8.74

2.73 
Table 1 (continued)

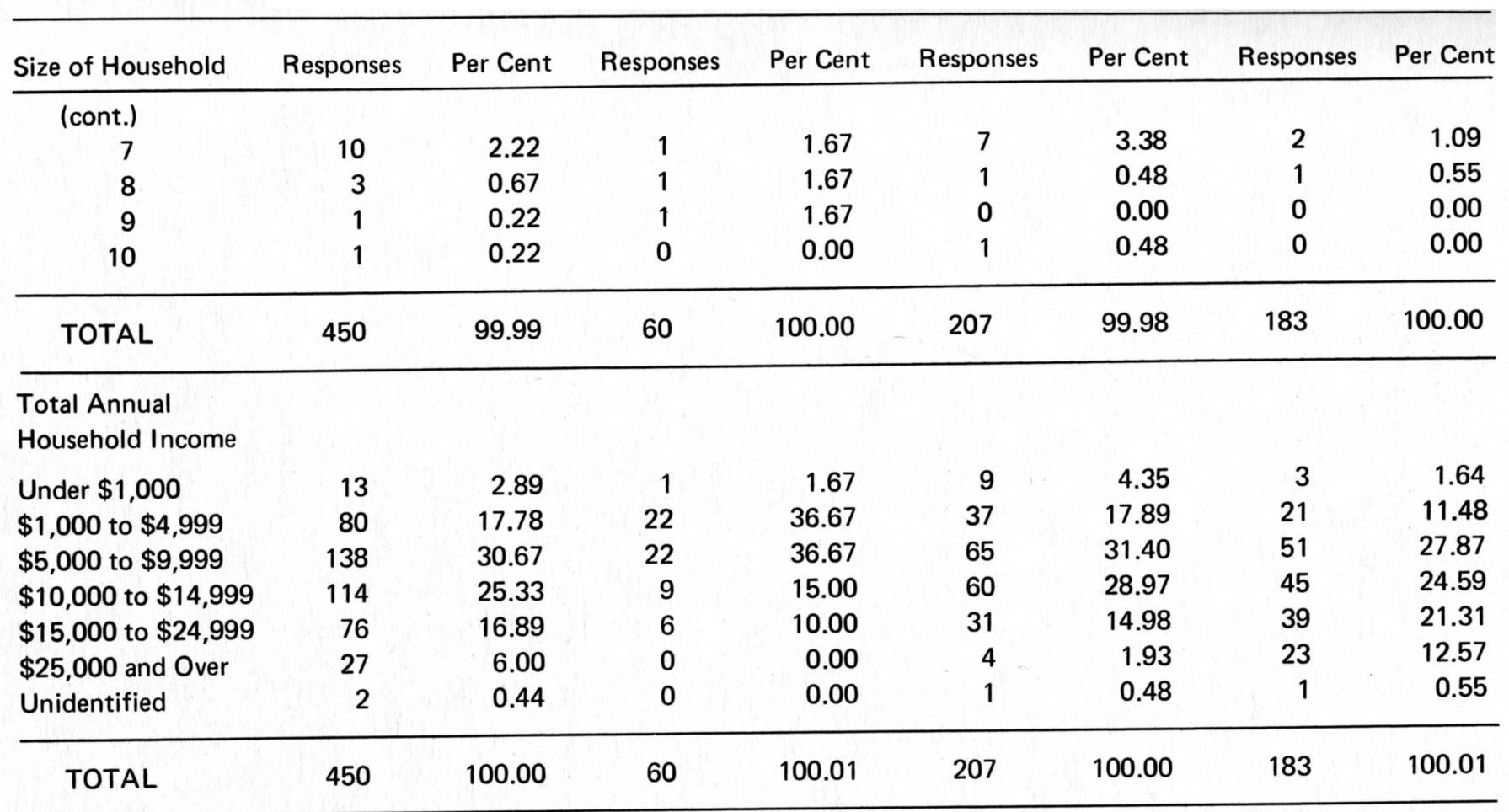

${ }^{a}$ Rounding errors may cause per cent totals to not equal 100.00 per cent. 


\section{CONFIDENTIAL \\ Survey Form \\ West Virginia University \\ Department of Agricultural Economics}

1. Which family member is most responsible for meat purchasing?
[ ] Wife
[ ] Husband
[ ] Other (write in)

2. Which family member is the principal income earner?
[ ] Wife
[ ] Husband
[ ] Other (write in)

3. Age of the principal income earner.

[ ] Under 25

[ ] $25-34$

[ ] $35-44$

[ ] $45-54$

[ ] $55-64$

[ ] 65 and over

4. Grade completed in school of the principal income earner.

[ ] 0 to 7 years

[ ] 8 years (grade school graduate)

[ ] 9 to 11 years

[ ] 12 years (high school graduate)

[ ] 13 to 15 years

[ ] 16 years (college graduate)

[ ] more than 16 years

5. Occupation of the principal income earner.

$\begin{array}{lllllll}\text { [ ] } & \text { Farmer } & \text { [ ] Self-employed [ ] } & \text { Service Worker } \\ \text { [ ] } & \text { Professional } & \text { [ ] Retired } & \text { [ ] } & \text { Craftsman } \\ \text { [ ] Housewife } & \text { [ ] Unemployed [ ] } & \text { Machine Operator } \\ \text { [ ] } & \text { Laborer } & \text { [ ] } & \text { White Collar } & \text { [ ] Sales and Clerical }\end{array}$

6. How many people (total number) are there living in your household?
[ ] 1
[ ] 4
[ ] 7
[ ] 2
[ ] 5
[ ] 8
[ ] 3
[ ] 6
[ ] more than 8 (write in) 
7. Into which of the following groups would your total annual household income fall (all family members)?
[ ] Under $\$ 1,000$
[ ] $\$ 1,000$ to $\$ 4,999$
I ] $\$ 10,000$ to $\$ 14,999$
[ ] $\$ 5,000$ to $\$ 9,999$
[ ] $\$ 15,000$ to $\$ 24,999$
[ ] $\$ 25,000$ and over

8. Has your consumption of meat changed over the last year?
[ ] Increased
[ ] Decreased
[ ] Same (no change)

9. Which county do you live in?

\section{West Virginia University Department of Agricultural Economics}

We need a complete report on the meats you and your household purchased at retail stores and ate during the last seven days or will eat during the next seven days from the time you receive this questionnaire. The quantity and current price of meats consumed from home freezers should be included. Do not include quantities or prices of meats consumed in restaurants.

If you should encounter any difficulty in deciding into which category various types of meats fall, then look at the list that follows.

\section{MEATS}

Beef

Steak, roast, stewing, ground, canned, corned, chipped, dried, and other.

Pork

Bacon, chops, ham, loin, sausage, salt pork, chipped, dried, and other.

Poultry

Chicken, turkey, duck, and other.

Seafood

Fresh, canned, shellfish, and other.

Lunch Meats

Bologna, salami, pickle loaf, goose liver, Spam, and other. 
BEEF Eaten Per Week

[ ] 0 to 1 pound

[ ] 1 to 2 pounds

[ ] 2 to 3 pounds

[ ] 3 to 4 pounds

[ ] 4 to 5 pounds

[ ] 5 to 6 pounds

[ ] 6 to 7 pounds

[ ] 7 to 8 pounds

[ ] 8 to 9 pounds

[ ] 9 to 10 pounds

[ ] 10 to 14 pounds

[ ] 15 pounds and over

\section{PORK Eaten Per Week}

[ ] 0 to 1 pound

[ ] 1 to 2 pounds

[ ] 2 to 3 pounds

[ ] 3 to 4 pounds

[ ] 4 to 5 pounds

[ ] 5 to 6 pounds

[ ] 6 to 7 pounds

[ ] 7 to 8 pounds

[ ] 8 to 9 pounds

[ ] 9 to 10 pounds

[ ] 10 to 14 pounds

[ ] 15 pounds and over

\section{POULTRY Eaten Per Week}

\begin{tabular}{|c|c|c|}
\hline ] & 0 to & 1 pound \\
\hline & 1 to & 2 pounds \\
\hline ] & 2 to & 3 pounds \\
\hline ] & 3 to & 4 pounds \\
\hline ] & 4 to & 5 pounds \\
\hline & 5 to & 6 pounds \\
\hline [ & 6 to & 7 pounds \\
\hline & 7 to & 8 pounds \\
\hline & 8 to & 9 pounds \\
\hline & 9 to 1 & 10 pounds \\
\hline & 10 to 1 & 14 pounds \\
\hline
\end{tabular}

Total Amount Spent Per Week

[ ] 0 to $\$ .99$

[ ] $\$ 1.00$ to $\$ 1.99$

[ ] $\$ 2.00$ to $\$ 2.99$

[ ] $\$ 3.00$ to $\$ 3.99$

[ ] $\$ 4.00$ to $\$ 4.99$

[ ] $\$ 5.00$ to $\$ 5.99$

[ ] $\$ 6.00$ to $\$ 6.99$

[ ] $\$ 7.00$ to $\$ 7.99$

[ ] $\$ 8.00$ to $\$ 8.99$

[ ] $\$ 9.00$ to $\$ 9.99$

[ ] $\$ 10.00$ to $\$ 14.99$

[ ] $\$ 15.00$ to $\$ 14.99$

\section{Total Amount Spent Per Week}

[ ] 0 to $\$ .99$

[ ] $\$ 1.00$ to $\$ 1.99$

[ ] $\$ 2.00$ to $\$ 2.99$

[ ] $\$ 3.00$ to $\$ 3.99$

[ ] $\$ 4.00$ to $\$ 4.99$

[ ] $\$ 5.00$ to $\$ 5.99$

[ ] $\$ 6.00$ to $\$ 6.99$

[ ] $\$ 7.00$ to $\$ 7.99$

[ ] $\$ 8.00$ to $\$ 8.99$

[ ] $\$ 9.00$ to $\$ 9.99$

[ ] $\$ 10.000$ to $\$ 14.99$

[ ] $\$ 15.00$ and over

Total Amount Spent Per Week

$\begin{array}{lll}\text { [ } & \text { ] } & 0 \text { to } \$ .99 \\ \text { [ ] } & \$ 1.00 \text { to } \$ 1.99 \\ \text { [ } & \text { ] } & \$ 2.00 \text { to } \$ 2.99 \\ \text { [ ] } & \$ 3.00 \text { to } \$ 3.99 \\ \text { [ ] ] } & \$ 4.00 \text { to } \$ 4.99 \\ \text { [ } & \text { ] } & \$ 5.00 \text { to } \$ 5.99 \\ \text { [ ] } & \$ 6.00 \text { to } \$ 6.99 \\ \text { [ } & \text { ] } & \$ 7.00 \text { to } \$ 7.99 \\ \text { [ ] } & \$ 8.00 \text { to } \$ 8.99 \\ \text { [ } & \text { ] } & \$ 9.00 \text { to } \$ 9.99 \\ \text { [ ] } & \$ 10.00 \text { to } \$ 14.99 \\ \text { [ } & \text { ] } & \$ 15.00 \text { and over }\end{array}$


SEAFOOD Eaten Per Week

[ ] 0 to 1 pound

[ ] 1 to 2 pounds

[ ] 2 to 3 pounds

[ ] 3 to 4 pounds

[ ] 4 to 5 pounds

[ ] 5 to 6 pounds

[ ] 6 to 7 pounds

[ ] 7 to 8 pounds

[ ] 8 to 9 pounds

[ ] 9 to 10 pounds

[ ] 10 to 14 pounds

[ ] 15 pounds and over

\section{LUNCH MEAT Eaten Per Week}

[ ] 0 to 1 pound

[ ] 1 to 2 pounds

[ ] 2 to 3 pounds

[ ] 3 to 4 pounds

[ ] 4 to 5 pounds

[ ] 5 to 6 pounds

[ ] 6 to 7 pounds

[ ] 7 to 8 pounds

[ ] 8 to 9 pounds

[ ] 9 to 10 pounds

[ ] 10 to 14 pounds

[ ] 15 pounds and over

\section{Total Amount Spent Per Week}

[ ] 0 to $\$ .99$

[ ] $\$ 1.00$ to $\$ 1.99$

[ ] $\$ 2.00$ to $\$ 2.99$

[ ] $\$ 3.00$ to $\$ 3.99$

[ ] $\$ 4.00$ to $\$ 4.99$

[ ] $\$ 5.00$ to $\$ 5.99$

[ ] $\$ 6.00$ to $\$ 6.99$

[ ] $\$ 7.00$ to $\$ 7.99$

[ ] $\$ 8.00$ to $\$ 8.99$

[ ] $\$ 9.00$ to $\$ 9.99$

[ ] $\$ 10.00$ to $\$ 14.99$

[ ] $\$ 15.00$ and over

\section{Total Amount Spent Per Week}

$\begin{array}{lll}\text { [ } & \text { ] } & 0 \text { to } \$ .99 \\ \text { [ } & \text { ] } & \$ 1.00 \text { to } \$ 1.99 \\ \text { [ } & \text { ] } & \$ 2.00 \text { to } \$ 2.99 \\ \text { [ } & \text { ] } & \$ 3.00 \text { to } \$ 3.99 \\ \text { [ } & \text { ] } & \$ 4.00 \text { to } \$ 4.99 \\ \text { [ } & \text { ] } & \$ 5.00 \text { to } \$ 5.99 \\ \text { [ } & \text { ] } & \$ 6.00 \text { to } \$ 6.99 \\ \text { [ } & \text { ] } & \$ 7.00 \text { to } \$ 7.99 \\ \text { [ } & \text { ] } & \$ 8.00 \text { to } \$ 8.99 \\ \text { [ } & \text { ] } & \$ 9.00 \text { to } \$ 9.99 \\ \text { [ } & \text { ] } & \$ 10.00 \text { to } \$ 14.99 \\ \text { [ } & \text { ] } & \$ 15.00 \text { and over }\end{array}$

If you and your household do not use meat in any form, then put a check mark in the blank below.

VONE

REMARKS: 
EXTRA FORMS FOR YOUR OWN USE

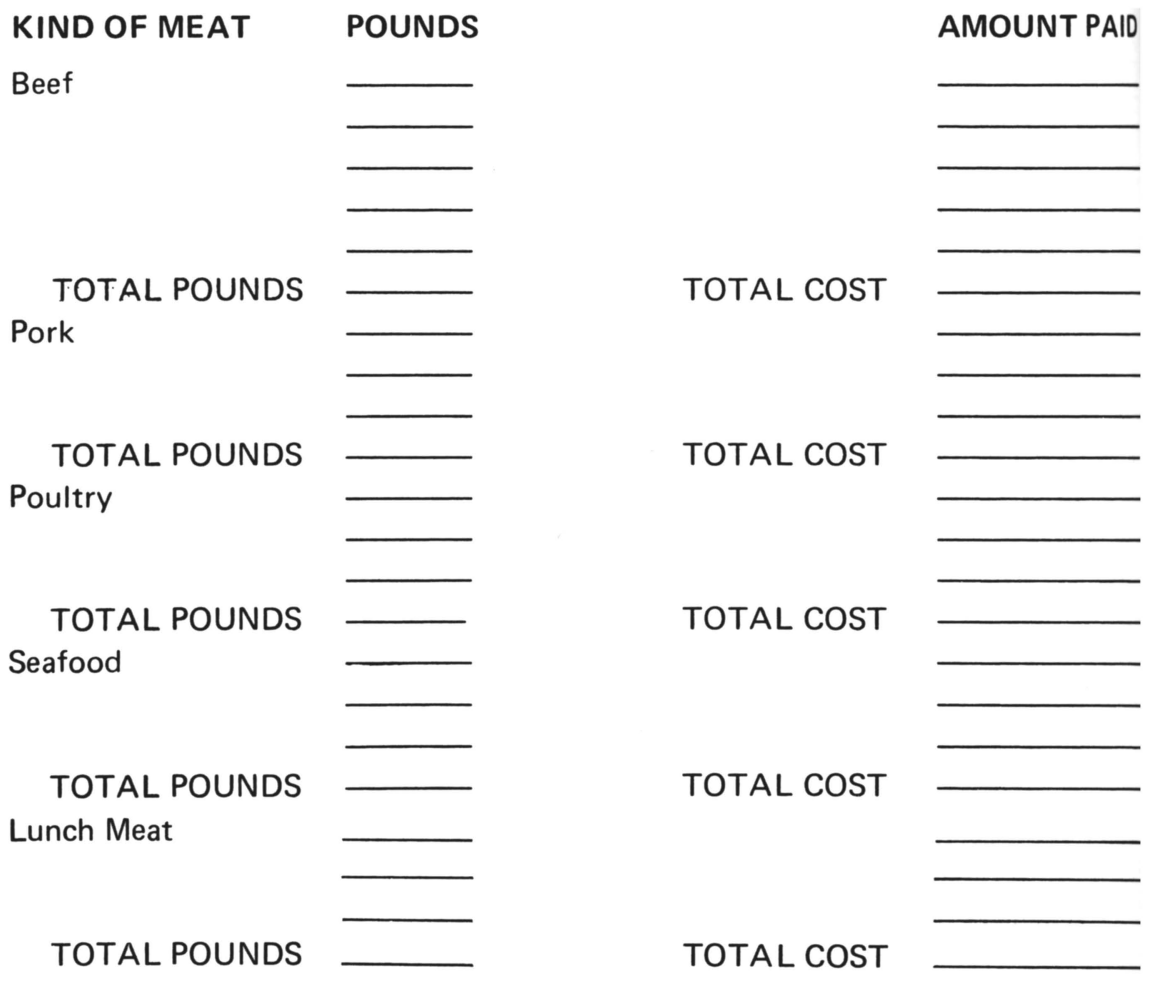

